Nuppu Koivisto

Säveltäjyys, sukupuoli, sanomalehtijulkisuus Vera Vinogradova-Bieckin ja Müna Härman toiminta sotienvälisessä Virossa

FT Nuppu Koivisto (nuppu.koivisto@uniarts.fi)väitteli syyskuussa 2019 Helsingin yliopiston Euroopan historian oppiaineessa 1800-luvun lopun naisorkestereista ja ylirajaisista varieteeverkostoista. Parhaillaan hän työskentelee Taideyliopiston Historiajoorumissa ja iyöstäa apulaisprofessori Susanna Valimäen (HY) kanssa
pitkällä 1800-luvulla syntyneitä säveltä̃viä naisia käsittelevää Sävelten tyttäret -tutkimushanketta. Koiviston tutkimusintressit keskittyvät erityisesti feministiseen musiikinhistoriaan sekä Itämeren piirin musiikkielämään 1800-1900-luvuilla.

DOI: https://doi.org/10.51816/musiikki.110826 
Composership, Gender, Press Reception: The Musical Practice of Vera Vinogradova-Bieck and Miina Härma in Interwar Estonia

This article focuses on the press reception and public image of two notable composers, Miina Härma and Vera Vinogradova-Bieck, in Estonia during the 1920s and 1930s. Härma, an organist and choral conductor, was - and still is - a celebrated figure in Estonian musical life due to the national romanticism in her creative output. Pianist and pedagogue Vera Vinogradova-Bieck, in turn, has been almost completely forgotten by music historians due to her musical modernism and her social position as a Russian émigré.

The study, based mostly on newspaper clippings, shows that there were significant differences in the press reception of Härma's and Vinogradova-Bieck's works, compositional styles and other musical activities. Gendered prejudice was evident in both cases, but on different terms due to language, age, and socioeconomic background: Härma was an established, influential public figure in Estonian nation-building, whereas Vinogradova-Bieck's fame was local and focused on Tallinn's Russian-speaking circles. Overall, I argue that the nexus of gender, class, canon, and nationalism forms a somewhat neglected but highly relevant set of problems for music history-writing in North-Eastern Europe, and that these problems can be tackled by careful feminist analysis. 


\section{Säveltäjyys, sukupuoli, sanomalehtijulkisuus \\ Vera Vinogradova-Bieckin ja Miina Härman toiminta sotienvälisessä Virossa}

Nuppu Koivisto

Vaikka kiinnostus sotienvälisen Viron musiikkielämään on viime vuosikymmeninä elpynyt (ks. esim. Lippus 1997; Lippus 2000; Lippus 2002), naisten sävellys- ja musiikkitoiminta on jäänyt siinä marginaaliseen asemaan. Monet merkittävät muusikot ja musiikkipedagogit kuten Erika Franz tai Aurora Semper odottavat edelleen elämäkertojensa kirjoittajia. Säveltaiteen alalta ylipäätään muistetaan parhaiten kansallisuusaatetta ajaneet vironkieliset tekijät siitäkin huolimatta, että 1920- ja 1930-lukujen Virossa opetettiin musiikkia, järjestettiin konsertteja ja sävellettiin muun muassa venäjäksi, saksaksi ja jiddišiksi (ks. Lippus 1997). ${ }^{1}$

Tässä artikkelissa haastan Viron musiikkielämän miehistä historiakuvaa tarkastelemalla kahta tuotteliasta säveltäjänaista - Vera Vinogradova-Bieckiä (1895?-1982)² ja Miina Härmaa (Hermann, 1864-1941) ${ }^{3}$ - vastaitsenäistyneessä Viron tasavallassa. Nämä kaksi hahmoa muodostavat mielenkiintoisen vastaparin. Yhtäältä he edustavat eri sukupolvia sekä kieli-ja kulttuuriryhmiä, pianisti Vinogradova-Bieck venäjänkielise-

1 Haluan kiittää kaikkia tekstiä kommentoineita - etenkin Musiikki-lehden refereelausunnonantajia, numeron päätoimittajaa Laura Wahlforsia sekä Taideyliopiston maaliskuun 2021 Torstaifoorumi-seminaarin osallistujia - arvokkaasta palautteesta kirjoitusprosessin aikana.

2 Tiedot Vinogradova-Bieckin syntymävuodesta vaihtelevat huomattavasti vuosien 1892, 1894 ja 1895 välillä. Tässä se on ilmaistu vanhimpien saatavilla olleiden alkuperäislähteiden eli Tallinnan vuoden 1922 henkilöllisyystodistusten luettelon ja vuoden 1927 osoiterekisterin mukaisesti (TNI, Isikuntunnistutse kontsud, Politsei VI jaoskond, TLA.186.1.457, 10868 Biek, Weera, Paul; TAB, Aadresslehed, TLA.1376.1.22, Biek, Weera).

3 Miina Härman alkuperäinen sukunimi oli Hermann, ja hän vironsi sen lokakuussa 1935 (Uus Eesti 26.10.1935). Vera Vinogradova-Bieck suosi itse yhdistelmäsukunimeä, mutta arvioissa hänestä saatettiin puhua esimerkiksi "Vinogradovana” (ks. esim. Päevaleht 17.3.1922). Vinogradova- ja Bieck-nimistä esiintyi lehdissä myös useita eri kirjoitusasuja. Selkeyden vuoksi käytän säveltäjien sukunimistä tässä artikkelissa vain edellä mainittuja nimimuotoja. 
nä emigranttina, juhlittu kuoronjohtaja-urkuri Härma puolestaan "kansallisen heräämisajan" (rahvuslik ärkamine, ärkamisaeg) merkkihenkilönä (ks. esim. Vaba Maa 10.2.1933; Postimees 8.2.1939). Toisaalta molemmat ammensivat ammattitaitonsa samasta opinahjosta, Pietarin konservatoriosta, ja vaikuttivat pitkään keisarikunnan pääkaupungissa.

Analyysissa keskitytään Vinogradova-Bieckin ja Härman asemaan sanomalehtijulkisuudessa. Sanomalehtijulkisuuden käsitteellä viittaan tässä yhteydessä siihen, miten pääasiallisesti miesoletetut, keskiluokkaiset toimittajat ja musiikkikriitikot heidän sävellystuotantoonsa virolaisissa sanomalehdissä ja julkisessa keskustelussa suhtautuivat. ${ }^{4}$ Millaisia sukupuolittuneita sävyjä keskustelusta on havaittavissa? Millaisia eroja teosten vastaanotossa mahdollisesti oli säveltäjien välillä? Entä miten tähän kaikkeen vaikuttivat Vinogradova-Bieckin ja Härman säveltäjäprofiili, sosioekonominen asema sekä kieli- ja kulttuuritausta - varsinkin, kun he edustivat eri sukupolvia? Pääväitteeni on, että molempien säveltäjien vastaanotto oli lehdistössä huomattavan sukupuolittunutta, mutta varsin eri tavoilla. Tällä perusteella esitän, että 1900-luvun alun säveltävien naisten uran ja teosten tutkimuksessa tulisi huomioida entistä herkkäsävyisemmin heidän työtään kehystävä poliittis-yhteiskunnallinen ilmapiiri.

Metodologisesti artikkeli edustaa feministisen, intersektionaalisesti suuntautuneen musiikinhistorian perinnettä (Citron 2000 [1993]; Grotjahn 2012; Ege 2018; Ege 2020; ks. myös Enefalk 2008). Naisoletettujen muusikoiden julkisuuskuvan "vastakarvaan luenta" (reading against the grain, ks. esim. Dolan 2012 [1988], 47) auttaa perkaamaan siihen liittyviä sukupuolittuneita elementtejä. Tarkoituksena ei ole niinkään ottaa kantaa siihen, miten Miina Härman ja Vera Vinogradova-Bieckin teokset asemoituvat suhteessa länsimaisen taidemusiikin patriarkaaliseen kaanoniin tai arvostella heidän tuotantoaan tämän kaanonin perinteisten "laadun" kriteerien näkökulmasta (ks. Torvinen 2020). Tavoitteena on pikemminkin tuoda esille niitä historiallisia sukupuolittuneita asenteita ja käytänteitä, jotka heidän julkiseen uraansa vaikuttivat.

Osaltaan artikkeli nivoutuukin muiden muassa Christina Scharffin, Mari Yoshiharan ja Anna Bullin viime vuosina vilkastuttamaan sosiologiseen keskusteluun luokasta, sukupuolesta ja rodullistamisesta klassisen musiikin alalla (Scharff 2017; Bull 2019; Yoshihara 2007). Tässä suhteessa tukeudun erityisesti Anna Bullin ja April L. Princen huomioihin musiikkimaailman sukupuolittuneisuuden ja luokkaidentiteettien

4 1800-ja 1900-luvun julkisen keskustelun sukupuolittuneisuutta suhteessa naisten musiikkitoimintaan ovat laajemmin avanneet uraauurtavissa tutkimuksissaan muiden muassa Freia Hoffmann (1998) ja Dorothea Kaufmann (1997). 
ilmentämisen ristiriitaisuuksista. Princen mukaan Clara Schumannia kuvaavissa maalauksissa ja valokuvissa musiikin tekemistä oli mahdollista esittää sekä 1800-luvun keskiluokkaisia sukupuolirooleja haastaen että niitä vahvistaen (Prince 2017, 135-136). Samankaltainen mekanismi toimi Bullin analyysiin pohjaten aikakauden konserttitilanteissa, joissa yhtäältä toisinnettiin keskiluokan käyttäytymisnormeja ja toisaalta mahdollistettiin niiden haastaminen (Bull 2019, 49). Esitän, että vastaava ristiveto näkyy tavassa, jolla Miina Härman ja Vera Vinogradova-Bieckin sukupuolta sekä sosiaalista ja kulttuurista taustaa käsiteltiin sotienvälisen Viron sanomalehdissä, ja että tällainen intersektionaalinen analyysi puoltaa paikkaansa feministisessä musiikinhistoriassa yleisemminkin.

Tutkimuksen ydinaineisto koostuu sanomalehdistä, joista suurin osa on Virossa digitoitu sotienväliseltä ajalta. ${ }^{5}$ Lehdistä on poimittu Härmaa ja Vinogradova-Bieckiä koskevat lehtileikkeet - yhteensä noin 2000 osumaa - optiseen tekstintunnistukseen perustuvan hakutoiminnon avulla. Vaikka toiminnossa on omat rajoitteensa, niitä on tasapainotettu käyttämällä mahdollisimman monia eri hakusanoja mahdollisimman monella eri kielellä (Miina Hermann, Miina Нärma, Мина/Миина Германъ, Миина Хярма; Vinogradova, Winogradowa, Виноградова, Bieck, Biek, Бикъ). Merkittävä osa aineistosta on vironkielistä, mutta leikkeiden joukosta löytyy myös saksan- ja venäjänkielisiä tekstejä. Määrällisesti Härmaa koskeva uutisointi painottuu 1930-lukuun, Vinogradova-Bieckin osalta taas 1920-luvun alkupuoleen. Vaikka kaikki leikkeet on käyty tätä tutkimusta varten läpi, aineiston lähiluku keskittyy kritiikkeihin, haastatteluihin, biografisiin artikkeleihin ja muihin laajamittaisiin teksteihin.

Etenkin Vinogradova-Bieckin kohdalla lehtiaineiston tukena on hyödynnetty myös muita lähde-editioita, kuten kirjeenvaihtoa, muistelmia ja painettuja nuotteja. Lähteiden saatavuuteen on valitettavasti vaikuttanut merkittävästi COVID-19-pandemia, jonka vuoksi arkistomatkat ovat olleet mahdottomia ja aineiston saatavuus Suomessakin katkolla lukusalisulkujen vuoksi. ${ }^{6}$ Sanomalehtiaineistoon painottuva analyysi ei

5 DIGAR-tietokanta, https://dea.digar.ee; ks. myös Zetterberg 2007, 598-599. Lisäksi artikkelissa on käytetty yhtä leikettä, joka on peräisin Latvian kansalliskirjaston Periodika-sanomalehtiportaalista (http://periodika.lv/). Tarkastelu on rajattu tässä yhteydessä sanomalehtiin: mahdollisia radiotallenteita ei ole ollut käytettävissä tutkimuksen tarkoituksiin.

${ }_{6}$ Monet kirjastot ja arkistot olivat kirjoitushetkellä (tammi-helmikuussa 2021) yleisöltä suljettuja. Pietarin konservatorion arkiston dokumentit (TsGIA SPB, fond 361, opis' 2, litšnye dela utšenits) digitoitiin Vinogradovan osalta koronapandemian aikana, mutta ne olivat kirjoitus- ja tutkimushetkellä käytettävissä ainoastaan Venäjältä käsin (ks. Pietarin konservatorion arkiston aineistoluettelo). Härman konservatoriotodistus sen 
ylipäätään anna kattavaa kokonaiskuvaa Vinogradova-Bieckin tai Härman omista poliittis-yhteiskunnallisista mielipiteistä, jotka muodostavat kokonaan oman tutkimusaiheensa. Tässä artikkelissa kysymys on ennen kaikkea säveltäjiin julkisuudessa kohdistuneista asenteista ja tyypittelyistä. Historiantutkimuksen etiikan perusperiaatteiden mukaisesti vältän kuitenkin Vinogradova-Bieckin ja Härman hahmojen typistämistä patriarkaatin uhreiksi ja korostan heidän oma-aloitteista, aktiivista toimijuuttaan musiikin kentällä (Frigren 2017, 62).

Kuten Urve Lippus (1995, 39-40) on todennut, sotienvälisen Viron musiikintutkimus ei neuvostodiktatuurin aikana ollut poliittis-ideologisista syistä erityisen suosittua. Aiemman tutkimuksen osalta tässä artikkelissa nojaudutaankin viime vuosikymmeninä julkaistuihin, Viron 1900-luvun alun musiikin historiaa käsitteleviin yleisteoksiin ja artikkeleihin (esim. Lippus 1995; Lippus \& Steinbach 2005; Lippus \& Sedrik 2008). Viron pianohistoriaa puolestaan on kartoittanut ansiokkaasti Virve Lippus (1997), joka on käsitellyt aihetta koskevassa tutkimuksessaan kursorisesti myös Vinogradova-Bieckin toimintaa Virossa.

Miina Härman kohdalla on ollut mahdollista tukeutua laajempaan biografiseen tutkimuskirjallisuuteen. Härmaa koskeva akateeminen tutkimus on kuitenkin edelleen vähäistä ja sävyltään ihannoivaa (Endre et al. 2014; Vahter 1971). Vinogradova-Bieckin suhteen tilanne on mutkikkaampi. Virossa ja muualla Euroopassa on kyllä tutkittu vilkkaasti venäläisiä emigrantteja, mutta musiikki ei ole ollut näissä julkaisuissa pääroolissa (ks. esim. Raeff 1990; Isakov \& Šor 2016-2017; Belobrovtseva \& Meimre 2015). Eesti Juudi Muuseumin sivuilla on kuitenkin saatavilla Mark Rybakin lyhyt elämäkertakuvaus Vinogradova-Bieckistä sekä hänen miehestään. Tekstin tukena on käytetty runsaasti materiaalia muun muassa Bieckien perhearkistosta Britanniasta (ks. Rybak: O Bikah). Sitä ei kuitenkaan ole lähdeviitoitettu, joten tietoihin on suhtauduttava varauksella.

Artikkeli jakautuu yhteen tausta- ja kahteen temaattiseen analyysilukuun, joita seuraa lyhyt johtopäätösosio. Ensimmäisessä luvussa esittelen Härman ja Vinogradova-Bieckin elämäntarinoita sekä heidän sävellystyötään yleisesti. Toisessa osiossa pohditaan heidän teostensa ja konserttiensa sukupuolittunutta vastaanottoa lehdistössä, kun taas kolmas luku keskittyy luokka-, kieli- ja kulttuuritaustaa sekä musiikkielämän poliittis-yhteiskunnallisia reunaehtoja koskeviin kysymyksiin. Koska Härmaa

sijaan on saatavilla baltialais-venäläisen Estlatrus-yhteisarkiston kautta (TsGIA SPB, fond 361, opis' 2, German, Minna [sic]). 
on tutkittu huomattavasti enemmän kuin Vinogradova-Bieckiä ja koska hänen teoksensa on jo aiemmassa tutkimuksessa kattavasti luetteloitu, olen keskittynyt artikkelin biografisessa perustutkimusosuudessa Vinogradova-Bieckiin sekä sisällyttänyt artikkelin loppuun hänen teoksistaan kokoamani listan. Vastaavasti Härman laajamittainen poliittinen toiminta on kasvattanut hänen osuuttaan varsinaisissa analyysiluvuissa.

\section{Säveltävänä naisena sotienvälisessä Virossa}

Miina Härman harteille on langennut monessa suhteessa tienraivaajan viitta Viron musiikin historiankirjoituksessa. Härma kuului ensimmäisiin korkeasti koulutettuihin vironkielisiin muusikoihin, sävelsi ensimmäisen vironkielisen näyttämöteoksen, niitti ensimmäisenä naisena laakereita kuoronjohdon ja urkujensoiton alalla sekä vihittiin ensimmäisenä naisena Tarton yliopiston kunniatohtoriksi (ks. esim. Päevaleht 12.2.1939). Virolaiskansallinen nationalismi ja naisasia-aate muodostavatkin Härman uran merkittävimmät kiintopisteet.

Miina Härma syntyi Viiu o.s. Pastakin ja kyläkoulun opettaja Johann Hermannin perheeseen vuonna 1864 Kõrvekülassa lähellä Tarttoa. Perheen kotikieli oli viro, ja kotona vaalittiin sekä kansallisuusaatetta että musiikin harrastusta (Päevaleht 9.2.1924; Endre et al. 2014, 16-20). Piano- ja sävellysopintonsa kotipiirin ulkopuolella Härma aloitti kuitenkin säveltäjä K. A. Hermannin ja pianisti Ernst von Knorren johdolla teiniiässä Tartossa. Lisäksi Härma lauloi Tartu-Maarjan seurakunnan kuorossa ja kartutti yleissivistystään Schulzen saksankielisessä tyttökoulussa (Endre et al. 2014, 22-25).

Tartossa ei 1880-luvulla ollut mahdollisuutta konservatoriotasoisiin opintoihin. Niinpä Härma pyrki ja pääsi 1880-luvun alussa Pietarin konservatorioon, jossa hän opiskeli seitsemän vuotta valmistuen Louis Homiliusin urkuluokalta ja opiskellen pääaineensa ohella laajasti teoria-aineita kuten sävellystä ja kontrapunktia (TsGIA SPB, fond 361, opis' 2, German, Minna [sic]; Eesti Postimees 3.2.1882; Endre et al. 2014, 3233). Pääkaupungin korkeat elinkustannukset kattaakseen Härma antoi opiskeluaikanaan yksityistunteja pianonsoitossa (Endre et al. 2014, 33). Pietarissa asui tuolloin runsaslukuinen vironkielisen ja nationalistisesti orientoituneen sivistyneistön joukko, jonka iltamiin, konsertteihin ja muihin tapahtumiin Härma otti innokkaasti osaa (Endre et al. 2014, 34-36). Konservatoriosta valmistuttuaan nuori säveltäjä-urkuri asettui- 
kin muutamiksi vuosiksi vakituisesti Pietariin. Syyt olivat käytännölliset: työmarkkinat olivat Pietarissa huomattavasti otollisemmat, eikä esimerkiksi urkurinvirkoja ollut Baltiassa tarjolla varsinkaan naiselle (Endre et al. 2014, 52). 1890-luvun alkuvuosina Härma kokeili menestyksekkäästi siipiään myös kansainvälisen tason konserttiurkurina Virossa, Leipzigissa, Lontoossa ja Helsingissä (Vahter 1971, 74-81).

1890-luvun puolivälissä Miina Härma kuitenkin palasi kotiseudulleen. Näihin aikoihin Härma perusti ensimmäisen sekakuoronsa ja aloitti näkyvän kuoronjohtotoimintansa laulujuhlilla - myös tässä suhteessa ensimmäisenä naisena (Postimees 1.7.1923). ${ }^{7}$ Vuosien saatossa Härmasta tuli suoranainen laulujuhlien voimahahmo, jota yleisö vaati hurraahuutojen saattelemana podiumille kerta toisensa jälkeen johtamaan suosittuja kuoroteoksiaan (ks. esim. Postimees 6.7.1923 ja 3.7.1928; Lääne Elu 28.6.1933). Kansallisten laulujuhlien viralliseksi laulunjohtajaksi häntä ei silti koskaan nimitetty sukupuolensa vuoksi (Endre et al. 2014, 168).

Miina Härman 16-vuotiaana aloittama julkinen sävellysura jatkui tuotteliaana läpi opiskeluajan, konserttikiertueiden ja kuoronjohtovelvoitteiden. Vokaalimusiikki muodosti leijonanosan Härman sävellystuotannosta, johon kuuluu myös kaksi laulunäytelmää, ja monet teoksista on sävelletty Härman johtamien kuorojen konserteissa esitettäviksi (ks. Härman teosluettelot, Endre et al. 2014, liite 5, 229-230; Vahter 1971, 149-155). Kansanlaulut ja kansanmusiikki olivat erityisen lähellä Härman sydäntä (Postimees 4.7.1921; ks. myös Sarv 2002, 280, 287). Ylipäätään Härma suosi sävellyksissään vironkielisiä tekstejä, esimerkiksi Lydia Koidulan sekä Anna Haavan lyriikkaa.

Vuonna 1904 Härma muutti Kronstadtiin, josta hänelle vapautui pianonsoitonopettajan paikka. Samoin kuin Pietarissa, myös Kronstadtissa asui 1900-luvun alussa vilkas vironkielinen yhteisö, jonka kulttuuritapahtumien voimahahmo Härmasta tuli (Endre et al. 2014, 121-136). Ensimmäisen maailmansodan sytyttyä Härma kuitenkin palasi Tarttoon, jonne hän jäi pysyvästi asumaan elämänsä loppuun saakka. Miina Härman panos Tarton musiikkielämässä olikin käänteentekevä: päivätyönsä eli tyttölukion laulunopettajan viran ohella Härma julkaisi uusia sävellyksiä sekä musiikkipedagogisia kokoelmia, järjesti konsertteja ja hyväntekeväisyystapahtumia, johti omaa sekakuoroaan sekä toimi Tarton säveltaiteen seuran (Tartu Helikunsti Selts) hallituksessa (Postimees 9.2.1934; Vahter 1971, 59-72). Aikalaiset lukivat Härman henkilökohtaiseksi ansioksi sen,

7 Laulujuhlien ja kansallisuusaatteen suhdetta Suomessa sekä yleisemmin on tutkinut Saijaleena Rantanen (esim. Rantanen 2013). Laulujuhlista Virossa ks. myös Puderbaugh 2006. 
että kaupungin musiikkikorkeakoulu saatiin pelastettua lakkautukselta 1920-luvun lopulla (ks. esim. Vaba Maa 10.2.1933).

Syntyjään venäläinen Vera Pavlovna Vinogradova-Bieck sen sijaan saapui Tallinnaan vasta 1920 -luvun alussa emigranttina ja toimi merkittävän osan sotienvälisestä ajasta Virossa pianopedagogina, -solistina ja säveltäjänä (ks. Lippus 1997, 116-117). Alun perin Vinogradova-Bieck oli kotoisin Volgan varrelta Nižni Novgorodin kauppa- ja teollisuuskaupungista, jossa hänen isänsä työskenteli valtion virkamiehenä (Judina 1999, 109; Rybak: O Bikah). Todennäköisesti Vinogradova-Bieck aloitti musiikkiopintonsa perhepiirissä, mikä oli ylemmässä keskiluokassa tyypillistä. Ammattiopintojen pariin nuori muusikonalku hakeutui vuonna 1911, jolloin hän kirjoittautui Pietarin konservatorioon (ks. Pietarin konservatorion arkiston aineistoluettelo). Pääaineinaan Vinogradova-Bieck opiskeli pianonsoittoa sekä sävellystä ja valmistui vuonna 1916 loistoarvosanoin (Lippus 1997, 116). ${ }^{8}$

Pietarissa Vera Vinogradova-Bieck tutustui nuoreen opiskelutoveriinsa, säveltäjä-kapellimestari Hermann Bieckiin, kirjanpainajan poikaan Tallinnasta (Judina 1999, 109). Pariskunta avioitui morsiamen kotikaupungissa vuonna 1918, keskellä sisällissodan sekasortoa (EELK Tallinna Niguliste Kogudus, II personaalraamat). Koti perustettiin kuitenkin Pietariin, josta molemmat saivat töitä pianonsoitonopettajina, Vinogradova-Bieck myöhemmin balettikorrepetiittorina (ks. Entsiklopeditšeskij slovar' Sankt-Peterburgskaja konservatorija, Mihejeva 2019).

Vinogradova-Bieck tähtäsi jo näinä vuosina määrätietoisesti julkiselle säveltäjänuralle, ja luomistyö oli pariskunnan kotona vauhdikasta. Läheinen perheystävä, huippupianisti Maria Judina on muistellut Bieckien Pietarin-aikaa seuraavasti:

Bieckien kotona, kahdessa pienessä huoneessa Torgovajalla, [...] Mariinski-teatterin ja Konservatorion läheisyydessä kuohui luomistyö, he molemmat sävelsivät paljon, me - erilaisissa kokoonpanoissa - soitimme

\footnotetext{
8 Tiedot opettajista vaihtelevat eri lähteissä ja tutkimuskirjallisuudessa: muiden muassa Jāzeps Vìtolsin, Maksimilian Steinbergin, Leonid Nikolajevin, Artur Lemban ja Vasili Kalafatin nimet on niiden joukossa mainittu (ks. esim. Poslednija izvestija 15.3.1922; Päevaleht 6.11.1934; Lippus 1997, 116; Judina 1999, 110, 112; Entsiklopeditšeskij slovar' Sankt-Peterburgskaja konservatorija, Vypuskniki 1865-1917 sekä Aleinikov \& Seliverstova 2014). Luotettavin tieto lienee Virve Lippusilla (1997, 116), joka viittaa tässä yhteydessä suoraan konservatorion asiakirjalähteisiin. Hän mainitsee Vinogradova-Bieckin opettajiksi Lemban, Nikolajevin, Kalafatin ja S. Ljapunovin. Sen sijaan painetuissa aikalaislähteissä ja muistelmissa korostuvat Nikolajevin lisäksi Vìtolsin sekä Steinbergin nimet.
} 
lukemattomia sinfonioita nelikätisesti; sen jälkeen juoksimme harjoituksiin teatteriin [...]. Verotška oli myös ihmeellinen emäntä, hän osasi toisinaan leipoa olemattomista aineksista milloin mitäkin piirakoita seuraavan preludinsa laatimisen tai yhden tai toisen oppitunnin välillä. ${ }^{9}$

Molempien Bieckien kamarimusiikki- ja orkesteriteoksia teoksia esitettiin 1920-luvun alussa sekä pienemmissä, puolijulkisissa iltamissa että yleisissä orkesterikonserteissa Pietarissa ja Moskovassa. Maria Judina soitti Hermann Bieckin Severnaja legenda -pianokonserton (suom. Pohjoinen legenda) jo vuonna 1921, ja vielä Bieckien emigroitumisen jälkeen keväällä 1924 hän esitti Vera Vinogradova-Bieckin kamarimusiikkiteoksia säveltäjän vierailukonsertissa Pietarissa (Judina 2006, 541, 562, 595). Hermann Bieckin teokset herättivät tosin julkisuudessa ja kollegoiden keskuudessa enemmän huomiota: Maria Judina kuvasi häntä suorastaan "säveltäjäksi Jumalan armosta" (kompozitor Božej milost’ju, Judina 1999, 114).

Sisällissotien ja varhaisen bolševikkihallinnon vuodet olivat kuitenkin Pietarissa fyysisesti ja taloudellisesti raskaita. Pulaa oli niin polttopuista kuin välttämättömistä elintarvikkeistakin. Kun Bieckit alkoivat odottaa ensimmäistä lastaan vuonna 1921, he päättivät muuttaa pysyvästi Tallinnaan Hermannin äidin ja perheen luo (Judina 1999, 114-115; ks. myös Poslednija izvestija 9.10.1921). ${ }^{10}$

Bieckien aktiivinen musiikkitoiminta Virossa alkoi heti syksyllä 1921, jolloin Hermann Bieck debytoi Tallinnassa pianistina (Päevaleht 2.11.1921 ja 19.11.1921). Vera Vinogradova-Bieck puolestaan aloitti pianopedagogin työnsä alkuvuodesta 1922 ja järjesti heti maaliskuussa ensimmäisen sävellyskonserttinsa (Päevaleht 18.2.1922; Revaler Bote 14.3.1922). Seuraavien vuosien aikana pariskunta vietti työntäyteistä elämää: kumpikin esiintyi, opetti ja sävelsi, minkä lisäksi Hermann Bieck johti Estonia-teatterissa sinfoniakonsertteja (ks. esim. Vaba Maa 8.4.1922) ja kiersi aktiivisesti konsertoimassa ulkomailla (ks. esim. Päevaleht 5.2.1924). Vera

9 ”В доме Биков, в двух комнатках на Торговой, [...] вблизи Мариинского театра и Консерватории, ключом кипела творческая жизнь, они оба много сочиняли, ми - в разных вариантах - играли безчисленные симфонии в 4 руки; потом бегали на репетиции [...] в театр [...]. Верочка была и чудесная хозяйка, умела порой из ничего испечь какие-то пирожки, между сочинением очередной прелюдии или тем или иным уроком." (Judina 1999, 109, 114).

${ }^{10}$ Bieckit asuivat 1920-luvulla Tallinnan vanhassakaupungissa osoitteessa Viru tänav 3-4 (EELK Tallinna Niguliste Kogudus, II personaalraamat; Biek, Herman \& Biek, Weera, Aadresslehed, TLA.1376.1.22; Päevaleht 18.2.1922). 
Vinogradova-Bieck puolestaan saavutti arvostusta pianopedagogina ja järjesti Tallinnassa lukuisia julkisia oppilasnäytteitä (ks. esim. Vesti dnja 22.12.1926 ja 2.4.1927).

Teoksiaan Vinogradova-Bieck onnistui 1920-luvulla saamaan läpi orkesteriohjelmistoihin, mikä oli useimmille tuon ajan säveltäjänaisille mahdotonta. Vuosina 1923 ja 1925 Estonia-teatterissa kuultiin jopa Vinogradova-Bieckin kaksi pianokonserttoa (Revaler Bote 20.4.1923 ja 2.12.1925; vrt. Lippus 1997, 116). Ensimmäisessä, E-duurikonsertossa solistina oli säveltäjä itse, toisen kantaesitti venäläinen tähtipianisti Nikolai Orloff. Ensimmäisen konserttonsa säveltäjä matkusti esittämään myös Pietariin kevättalvella 1924 (Judina 2006, 78, 81, 563).

Tyypillisesti Tallinnan ja Helsingin kaltaiset pienemmät Itä-Euroopan kaupungit toimivat väliaikaisina kauttakulkuetappeina 1920-luvun alun venäläisille emigranteille, joiden varsinaisena päämääränä olivat Riian, Berliinin tai Pariisin laajemmat työmarkkinat (ks. esim. Belobrovtseva \& Meimre 2015, 34-35). Näin oli myös Bieckien tapauksessa siitä huolimatta, että heillä oli vahvat perhesiteet Tallinnaan. Vuonna 1927 Vera Vinogradova-Bieck siirtyi pysyvästi Berliiniin, josta hänen miehensä oli saanut paikan Klindworth-Scharwenka-konservatorion opettajana (TAB, Aadresslehed, TLA.1376.1.22, Biek, Herman \& Biek, Weera; Vesti dnja 3.6.1927). ${ }^{11}$ Kokonaan yhteydet Viroon eivät kuitenkaan katkenneet: esimerkiksi kesällä 1928 Vinogradova-Bieck vieraili Haapsalussa kylpyläsesongista nauttimassa (Vesti dnja 17.8.1928; Revaler Bote 18.9.1928).

Saksassa Vera Vinogradova-Bieck jatkoi säveltäjänuraansa, ja sekä pariisilainen Édition russe de musique -kustantamo että berliiniläinen Balan julkaisivat 1930-luvun alkuvuosina joitakin hänen pianoteoksiaan (ks. liite). Natsien valtaannousu kuitenkin katkaisi lupaavasti alkaneen Berliinin-kauden: juutalaistaustaisena Hermann Bieckin oli perheineen lähdettävä maasta vuonna 1933. Siitä alkaen Bieckit - varsinkin Vera - asuivat jälleen pitempiä aikoja Tallinnassa (Vaba Maa, Pärnu väljaanne 14.7.1933; Vesti dnja 5.12.1933; Päevaleht 6.11.1934; Uudisleht 31.1.1936).

Tallinnaan asetuttuaan Vinogradova-Bieck jatkoi työtään niin esittävänä taiteilijana kuin säveltäjänäkin ja perusti pianostudionsa uudelleen (Uudisleht 4.6.1935; Vaba Maa 23.11.1935). Hän sai jälleen laajempiakin orkesteri- ja kamarimusiikkiteoksiaan - kuten pianotrion, jousikvarteton sekä Balladin pianolle ja orkesterille - julkisuuteen muun muassa Viron akateemisen säveltaiteen seuran (Eesti akadeemiline helikunsti selts)

${ }^{11}$ Berliinissä Hermann Bieck loi myös menestyksekästä uraa viihdeorkesterin kapellimestarina ja säveltäjänä taiteilijanimellä Ben Berlin (ks. esim. Päevaleht 3.6.1930). 
tilaisuuksissa sekä radiossa (ks. esim. Päevaleht 6.11.1934; 17.10.1936; 18.3.1939).

Hermann Bieck oli jatkanut Berliinin-kauden jälkeen aktiivista kansainvälisen konserttipianistin uraa asettuen lopulta Lontooseen, jonne myös muu perhe siirtyi pysyvästi vuonna 1936 (Deutsche Zeitung 28.9.1934; Uudisleht 31.1.1936 no 18 s. 7). Keväällä 1938 seurasi matka New Yorkiin, jossa Vera Vinogradova-Bieck debytoi omalla sävellyskonsertillaan (Päevaleht 26.6.1938). Samana vuonna Vinogradova-Bieck sai julki Toccatinansa pianolle lontoolaisessa Augener-kustantamossa (ks. liite). Baltiassa säveltäjä kuitenkin vieraili edelleen kesänvietossa sekä konsertoimassa aina toisen maailmansodan syttymiseen saakka (ks. esim. Vesti dnja 24.3.1939).

Hermann Bieck menehtyi pian Lontooseen-muuton jälkeen (Judina 1999, 115), jolloin Vera Vinogradova-Bieck otti päävastuun perheen elatuksesta perustamallaan yksityisellä musiikkikoululla. Koulusta tuli menestyksekäs, ja Vinogradova-Bieckin johdolla opiskeli useita legendaarisia brittitaiteilijoita kuten teatteriohjaaja Peter Brook (ks. Brook 2017, 26-29). Pedagogina Vinogradova-Bieck oli ylipäätään innostava ja avarakatseinen: aikalaiskuvausten mukaan hänen koulussaan ei keskitytty ainoastaan soittotekniikkaan vaan esittävien taiteiden laaja-alaiseen ymmärrykseen. Brook toteaakin muistelmissaan, että Vinogradova-Bieckin musiikkitunnit olivat hänen "ainoa näyttämötaiteen opinahjonsa" ( $m y$ only dramatic academy, Brook 2017, 29).

Ensi silmäyksellä Miina Härman ja Vera Vinogradova-Bieckin elämänpolut näyttävät poikkeavan dramaattisesti toisistaan. Härman ura on helppo nähdä teleologisena, yksisuuntaisena tienä johtotähtenään virolaiskansallinen nationalismi, Vinogradova-Bieckin kohtalo puolestaan stereotyyppisenä juureton emigrantti -muunnelmana. Niistä on kuitenkin löydettävissä myös leikkauspintoja ja yhtymäkohtia. Ensimmäinen maailmansota, Venäjän vallankumous ja sisällissodat sekoittivat yhtä lailla molempien elämän ja tulevaisuudensuunnitelmat, joissa keisariajan Pietari lähiympäristöineen oli näytellyt merkittävää roolia. Ilman näitä maailmanpoliittisia mullistuksia Härma ei välttämättä olisi koskaan palannut Tarttoon ja Vinogradova-Bieck tuskin olisi muuttanut eläessään Tallinnaan. 


\section{"Viron sävelteosten kuningatar"12 ja "oman tiensä kulkija": sukupuolittuneisuus sanomalehtijulkisuudessa}

Julkisen säveltäjänuran valinneina naisina Vera Vinogradova-Bieck ja Miina Härma olivat aikalaistensa silmissä lähtökohtaisesti poikkeuksellisia hahmoja. Härman teoksia oli arvioitu Viron sanomalehdissä aktiivisesti jo 1800-luvun lopulta alkaen, mutta 1930-luvulle tultaessa hänen kiivas esiintymistahtinsa oli ehtinyt rauhoittua yksittäisiä konsertteja lukuun ottamatta ja tuotteliain sävellyskausi oli jo takanapäin. Hänen tuotantoaan esitettiin silti ahkerasti erilaisissa konserteissa ja tilaisuuksissa, minkä vuoksi niistä myös kirjoitettiin sanomalehdissä jatkuvasti (esimerkkinä ks. Postimees 11.2.1924). Härman tasavuosisyntymäpäivät olivat kansallisia merkkitapauksia, joita juhlistettiin näyttävin menoin Tallinnan Estonia- sekä Tarton Vanemuine-teattereissa. Toimittajat raportoivat juhlahumusta yksityiskohtaisesti kuvien, haastattelujen ja puheiden kera - eivät ainoastaan Tartossa ja Tallinnassa, vaan pienilläkin paikkakunnilla ympäri maan (ks. esim. Postimees 11.2.1934; Maa Hääl 6.2.1939).

Vera Vinogradova-Bieckin ura sen sijaan oli sotienvälisenä aikana vasta nousukiidossa. Hänen orkesteri- ja kamarimusiikkikonserttejaan kyllä arvioitiin vironkielisessä päivälehdistössä, mutta yksityiskohtaisimmin hänen elämänvaiheistaan kirjoittivat tallinnalaiset emigranttilehdet kuten Vesti dnja ja Naša gazeta. Vaikka Vinogradova-Bieckistä ajoittain puhuttiin lehdissä paikallisena säveltäjänä (Vesti dnja 31.1.1936) ja vaikka hän sai teoksiaan esimerkiksi Estonia-teatterin orkesterikonsertteihin, häntä arvostettiin ennen kaikkea venäjänkielisen yhteisön sisällä. Vinogradova-Bieckistä ei virolaisessa lehdistössä julkaistu tiettävästi laajamittaisia haastatteluja tai elämäkerta-artikkeleita, vaan leikkeissä painottuvat konserttikritiikit ja -ilmoitukset, konserttitoimistojen "puffit" sekä lyhyet uutistekstit.

Miehensä kautta Vinogradova-Bieckillä oli kuitenkin virolaiseen musiikkimaailmaan kytköksiä, joiden avulla solistisia esiintymisiä ja sävellyskonsertteja oli ylipäänsä mahdollista järjestää. Perheystäviin kuului muun muassa sittemmin Yhdysvaltoihin muuttanut pianisti Vladimir Padva, joka peri Vinogradova-Bieckin pianoluokan tämän muutettua Berliiniin vuonna 1927 (Naša gazeta 16.9.1927; Päevaleht 26.6.1938). Toisaalta kontakteihin vaikuttivat Pietarin konservatoriossa solmitut ystävyydet ja tuttavuudet, sillä opinahjosta valmistui useita vironkielisiä ja

12 ”Eesti helitööde kuninganna”, Päevaleht 11.2.1934. 
baltiansaksalaisia muusikoita keisariajan lopulla (ks. esim. Lippus 1997, $62)$.

Sukupolvi- ja verkostoerojen ohella Härman ja Vinogradova-Bieckin teosten vastaanottoon vaikuttivat heidän erilaiset sävellysestetiikkansa. Siinä missä Härman tuotanto koostui pääasiallisesti kansallisromanttisessa hengessä kirjoitetusta ja kansanmusiikista inspiroituneesta vokaalimusiikista, Vinogradova-Bieck edusti nuoremman polven modernistisekspressionistista, tonaalisuuden rajoilla liikkuvaa musiikillista ajattelua (ks. Vinogradova-Bieck 1930a, 1930b ja 1933). Tästä huolimatta musiikkiarvioitsijoiden teksteistä löytyy kummankin säveltäjän kohdalla osittain yhteneviä ja leimallisen sukupuolittuneita täsmäkritiikin kohteita.

Useimpia Miina Härman teoksia ei sotienvälisenä aikana varsinaisesti arvioitu sanomalehdissä, sillä hänen suositut yksinlaulunsa ja kuoroteoksensa olivat jo laajasti yleisön tuntemia. Teosten kuvailu oli pikemminkin laveaa ja maalailevaa, joskin pääsävyltään ristivetoista. Yhtäältä artikkeleissa korostettiin säveltäjän "energistä" (energiline, ks. esim. Päevaleht 11.2.1924) ja "tulisieluista" (tulihingeline, ks. esim. Päevaleht 6.2.1939) luomisvoimaa. Sen tuloksina nähtiin muun muassa suoranaiseksi virolaisten "mieskuorojen yhteiseksi hymniksi" (meeskooride ühine hümn, Postimees 28.5.1938) noussut Meeste laul sekä niin ikään suosittu Sõjalaste marss. Esmaspäev-lehden nimimerkki "Siil" kuvasi Härmaa jopa "säveltemme Suvoroviksi" kuuluisaan venäläiskenraaliin viitaten (meie helide Suvorov, Esmaspäev 4.2.1939). Toisaalta musiikkikirjoittajat - esimerkiksi säveltäjä Juhan Aavik - pitivät Härman tuotannolle leimallisina "herkkää lyriikkaa" ja "sydämellistä lämpöä" (õrn lüürika, südamlik soojus; ks. esim. Päevaleht 12.2.1924 ja 6.2.1939; Postimees 8.2.1939).

Tämän vastakkainasettelun voi tulkita Robert Schumannin tunnetun Florestan-Eusebius-vastaparin jatkona, kuten esimerkiksi Artur Vahter tekee Härma-elämäkerrassaan (Vahter 1971, 94). Luonnehdintoihin kuitenkin liittyi voimakas binäärinen, heteronormatiivinen sukupuolittuneisuus, jossa herkkyys ja lyyrisyys tulkittiin naisellisiksi ja energisyys sekä sankarillisuus miehisiksi säveltaiteellisiksi ominaisuuksiksi (ks. esim. Esmaspäev 4.2.1939). Härman mieskuoro- ja marssimuotoisia teoksia soitettiinkin aktiivisesti muun muassa suojeluskuntien tilaisuuksissa (ks. esim. Kaja 8.7.1935). Erityisesti Meeste laul -mieskuoroteoksen yhteydessä Härmasta kirjoittaneet musiikkiammattilaiset ja reportterit ilmaisivat ylpeydensekaista hämmästystään siitä, että tämän heidän mukaansa maskuliinis-kansallista voimaa ja uhoa uhkuvan sävellyksen oli laatinut nainen. 
Tällaisen ristiriitaisuuden ja erityislaatuisuuden korostamisella Miina Härmasta leivottiin sanomalehtijulkisuudessa säveltäjänä ikään kuin sukupuolensa rajat ylittänyt poikkeus, joka vahvisti säännön. Epätyypillisyyden korostaminen näkyi teosluonnehdintojen ohella tavassa, jolla Härmaan suhtauduttiin muilla musiikkiammattilaisuuden osa-alueilla, kuten kuoronjohtajana. Esimerkiksi Esmaspäev-lehden toimittaja riimitteli kesän 1923 laulujuhlia käsittelevässä reportaasissaan: "Kyllä Miina tietää, miten Miesten laulun pitää kajahtaa!” (Küll Miina teab, kuidas Meeste laul kõlama peab, Esmaspäev 9.7.1923).

Kahtiajako vaikutti Härman kohdalla epäsuorasti hänen teostensa keskinäiseen vertailuun. Vaikka Härman Kalev ja Linda -näyttämöteoksesta (1895) esitettiin sotienvälisenä aikana etenkin yksittäisiä, suosittuja laulunumeroita, kollegat eivät antaneet hänen laajamuotoisemmille sävellyksilleen suhteellisesti paljonkaan arvoa esseissään, kritiikeissään ja juhlapuheissaan (ks. esim. Postimees 11.2.1924). Ajoittain näissä kokonaistuotantoon liittyvissä näkemyksissä korostuivat myös Härman ikä ja sukupolvi. Esimerkiksi Maa Hääl -lehden toimittaja puolestaan ihasteli säveltäjän 75-vuotisjuhlakonsertissa "kaunista kuvaa: harmaahapsinen säveltäjä valkeassa leningissä taustallaan mieslaulajien musta frakkimuuri" ${ }^{13}$ Raadio-lehden anonyymiksi jäänyt toimittaja puolestaan arvosteli vuonna 1939 Härman tuotantoa omaperäisyyden puutteesta viitaten sentimentaalisina ja vanhakantaisina pitämiinsä tyylipiirteisiin, joiden hän katsoi kumpuavan vieraasta, baltiansaksalaisen aatelin laulukulttuurista pikemmin kuin ehdasta virolaisesta kansanperinteestä (Raadio 26.1.1939).

Myös Härmaan henkilönä liitetyt epiteetit heijastavat lehtikirjoittelun ristiriitaisia ja poikkeuksellisuus-diskurssiin sitoutuneita sävyjä. Miina Härmasta saatettiin kyllä puhua näennäisen neutraalisti yhtenä Viron suurimmista säveltäjistä, jolloin häneen liitettiin korkeaan ikään ja arvostettuun asemaan viittaavia attribuutteja kuten "kunnianarvoisa" (auväärt), "kunnioitettu" (lugupeetud), "hopeahapsinen" tai "harmaahapsinen" (hõbepea, hallpea). Toisaalta korostettiin säveltäjän loppumatonta tarmoa ja "ikuisesti nuorta" (igavesti noor) persoonaa (ks. esim. Päevaleht 3.2.1939). Otsikoihin päätyi kuitenkin ajoittain sana "naissäveltäjä" (naishelilooja, ks. esim. Sakala 8.2.1939), ja lehdissä mainittiin usein eräänlainen kansallisten suurnaisten "trio", johon kuuluivat ikätoverukset, runoilija Anna Haava, sopraano Aino Tamm ja Miina Härma (esim. Vaba

13 "[...] ilus pilt: valges kleidis hallpäine helilooja meeslauljate musta frakimüüri taustal." Maа Hääl 6.2.1939. 
Maa 4.3.1934; Esmaspäev 4.2.1939). Sikäli kuin lehdissä julkaistiin Viron musiikkielämän ja laulujuhlien historiasta kertovia pitempiä artikkeleita tai kuvareportaaseja, Härma oli poikkeuksetta joukon ainoa nainen (ks. esim. Postimees 1.7.1923).

Vera Vinogradova-Bieckin kohdalla tilanne oli monessa mielessä toisenlainen. Vinogradova-Bieckiä koskevissa harvoissa yleisluontoisemmissa artikkeleissa tai uutisteksteissä eksplisiittistä sukupuoleen liittyvää kummastelua esiintyi vain vähän (esimerkkeinä ks. Revaler Bote 14.3.1922; Poslednija izvestija 15.3.1922). Varsinaisissa musiikkikritiikeissä sukupuolittuneisuus sen sijaan nousi herkemmin pinnalle. VinogradovaBieckiä pianotaiteilijana käsittelevät arviot olivat yleissävyltään arvostavia ja positiivisia kaiken kielisissä lehdissä, vaikka arvioitsijat ajoittain esittivät eriäviä tulkinnallisia mielipiteitä (ks. esim. Tallinskij russkij golos 10.3.1934). Myötäsukaisiin kritiikkeihin saattoi silti liittyä sukupuolittunut lataus, jossa näkyi samankaltainen nais-mies-vastakkainasettelu kuin Miina Härman sävellysten kohdalla. Kun Vinogradova-Bieck huhtikuussa 1922 esitti Beethovenin "Keisarikonserton" (no 5 Es-duuri) sinfoniaorkesterin solistina Estonia-teatterissa, Revaler Boten ja Päevaleht -lehden kriitikko -h- kommentoi soittoa seuraavasti:

Tosin sille, joka on kuullut esim. Arthur Schnabelin soittavan tämän konserton, tulee selväksi ero alkuvoimaisen, hallitun voiman ja ainoastaan satunnaisen voimankehityksen välillä. Näyttääkin siltä, että tästä konsertosta on olemassa miehinen ja naisellinen tulkinta, kumpikin omalla tavallaan oikeutettu. ${ }^{14}$

Edellä mainitun nimimerkki -h-:n ohella Vinogradova-Bieckin konsertteja ja sävellyksiä arvioivat 1920-luvun tallinnalaisessa lehdistössä muun muassa Sergei Gorin venäjäksi sekä veljekset, pianisti Theodor Lemba ja säveltäjä Artur Lemba viroksi sekä saksaksi. Etenkin Lemban veljekset, joista Theodor toimi Päevaleht- ja Artur Vaba Maa -lehden kriitikkona, käyttivät merkittävää sanavaltaa pääkaupungin kulttuurikeskustelussa. Molemmat olivat opiskelleet ja opettaneet Pietarin konservatoriossa, ja molemmilla oli vahva institutionaalinen asema Tallinnan ja Viron musiikkielämässä (Lippus 1997, 53-63). Lembat esiintyivät ajoittain samois-

14 "Freilich, wer z. B. Arthur Schnabel dieses Konzert hat spielen hören, dem wird der Unterschid zwischen elementarer, beherrschter Kraft und nur gelegentlicher Kraftentfaltung klar sein. Es gibt eben, wie es scheint, eine männliche und eine weibliche Interpretation dieses Konzerts, beide in ihrer Arte berechtigt.” Revaler Bote 12.4.1922. Kritiikki julkaistiin viron kielellä myös Päevaleht-julkaisussa samana päivänä. 
sa tilaisuuksissa Bieckien kanssa, ja todennäköistä on, että kaikki neljä tunsivat toisensa henkilökohtaisesti jo konservatorioajoilta (ks. esim. Revaler Bote 7.12.1922; Poslednija izvestija 24.12.1923).

Vinogradova-Bieckin sävellystyöhön sekä Theodor että Artur Lemba suhtautuivat 1920-luvulla varsin kriittisesti. Kysymys oli pohjimmiltaan taidefilosofisista näkemyseroista. Siinä missä Vinogradova-Bieck oli sävelkieleltään ekspressionisti, varsinkin Artur Lemba suhtautui moderniin musiikkiin epäluuloisesti. Kun esimerkiksi Hermann Bieck esitti pianoillassaan helmikuussa 1924 Maurice Ravelin sonatiinin, Artur Lemba esitti paheksuntansa teoksen kolmannen osan "äärimodernismista" (ultramodernism, Päevaleht 5.2.1924). Theodor Lemba puolestaan kritisoi Hermann Bieckin samana vuonna Tallinnassa esitettyä sinfoniaa suorasanaisesti liiasta uudenaikaisuudesta (Päevaleht 10.2.1924).

Vinogradova-Bieckin molempia pianokonserttoja Artur Lemba moitti ankarasti muun muassa yhtenäisyyden ja omien ideoiden puutteesta, hakkaavien oktaavijuoksutusten viljelystä sekä foxtrot-motiivien käytöstä (Vaba Maa 22.4.1923 ja 9.12.1925). Kriittisiin lausuntoihin yhtyi Theodor-veli, joskin vähemmän kärkkäästi (Päevaleht 22.4.1923 ja 8.12.1924). Poslednija izvestija -lehden nimimerkki G. T-ov sen sijaan oli toisen pianokonserton arviossaan (6.12.1925) rohkaisevampi teoksen rakennetta koskevista kriittisistä huomioistaan huolimatta.

Vaikka säveltäjän sukupuolta ei kaikissa arvioissa tai kaikkien teosten kohdalla nostettu erikseen esiin, sillä oli vaikutuksensa kritiikin yleissävyyn. Nimimerkki -h- aloitti arvionsa Vinogradova-Bieckin sävellysdebyytistä Tallinnassa keväällä 1922 todeten, ettei "ole ihme, että modernin musiikkisuuntauksen piirissä, jossa kokeilemiselle, yksittäisten mielialojen hyödyntämiselle annetaan niin suurta painoarvoa, naiset ovat sävellyksen alalla aktiivisempia kuin aiemmin. Ja siltikään ei moderni musiikkituotanto ole tuonut tullessaan merkittävämpiä naissäveltäjiä." ${ }^{15}$ Artur Lemba sen sijaan oli Vinogradova-Bieckin toista pianokonserttoa arvioidessaan suorasanaisen misogyyninen:

Naisilta ylipäänsä puuttuu mielikuvitus [fantaasia], ja sikäli kuin luomistyö ilman mielikuvitusta on mahdotonta, on myös ymmärrettävää, mistä syystä musiikin historiasta ei ole löydettävissä ainuttakaan merkittävämpää naissäveltäjää. Rva Vinogradovan sävelteoksen yhteydessä

15 "Ei tule imeks panna, kui moderni muusikaltse [sic] suuna juures, mil eksperimenteerimise, üksikute tujude kasutamise peale nii suurt rõhku pannakse, naised enam kui varem kompositsiooni alal tegevad on. Ja siiski ei ole ka modern muusikaline produktsioon seni suurema tähendusega naiskomponiste toonud.” Päevaleht 17.3.1922. 
voisi käyttää Lessingin sanoja, joilla tämä luonnehti erään kirjan sisältöä: "siinä on paljon uutta ja hyvää, harmillista vain, että se, mikä on uutta, ei ole hyvää, ja se, mikä on hyvää - ei ole uutta."16

Tämä asenne ei kuitenkaan estänyt Lembaa kirjoittamasta arvostavasti Miina Härman lauluteoksista (Vaba Maa 9.2.1934). Todennäköisesti Lemban oli helpompi suhtautua positiivisesti vironkielisen Härman sävellyksiin tämän etabloituneen aseman vuoksi sekä siksi, että Härman tuotanto keskittyi vokaalimusiikkiin, naisille sosiaalisesti hyväksyttyyn säveltaiteen haaraan. Konserttomuodolla Vinogradova-Bieck astui alueelle, joka 1920-luvun Virossa oli vielä täysin miesten hallinnassa. Luultavimmin Lemba koki laajamittaisiin orkesteri- ja kamarimusiikkiteoksiin erikoistuneen Vinogradova-Bieckin ammatillisesti uhkaavaksi kilpailijaksi maan pienehköllä säveltaiteen kentällä.

1920-luvun vironkielisen lehdistön pianokonserttoarviot olivat osittain ristiriidassa sen kanssa, mitä teoksista ja Vinogradova-Bieckin sävellysteknisestä osaamisesta sanottiin muualla. Esimerkiksi pietarilainen säveltäjä ja professori Maksimilian Steinberg esitti jos ei varauksettoman positiivisia, vähintäänkin rohkaisevia arvioita hänen ensimmäisestä pianokonsertostaan (Judina 2006, 563). Latvialainen lehti Rigasche Rundschau puolestaan suitsutti Vinogradova-Bieckiä omaperäisenä "taiteilija[na], joka tarmokkaasti kulkee omaa tietään eikä vaikuta olevan valmis tekemään lainkaan myönnytyksiä". ${ }^{17}$ Vinogradova-Bieckin pianoorkesteriteosten mielenkiinnosta viestii sekin, että niitä soittivat Nikolai Orloffin ja Aleksandr Borovskin kaltaiset kansainvälisen tason konserttipianistit (Vaba Maa 3.10.1930).

Kun Vera Vinogradova-Bieck 1930-luvulla palasi Tallinnaan ja sai siellä esitettyä piano- sekä kamarimusiikkiaan, oli kriitikoidenkin suhtautuminen merkittävästi suopeampaa myös vironkielisissä lehdissä. Joukosta ei löydy Lemban veljesten arvioita, mikä lienee vaikuttanut keskustelun sävyyn. Esimerkiksi tarttolaiseen Postimees-lehteen kirjoittanut säveltäjä Riho Päts kiitti Vinogradova-Bieckin pianotrioa innovatiivisesta rytmin käsittelystä ja yksinlauluja niiden ”omaperäisestä, terävästä huu-

16 "Naistel üldse puudub fantaasia, kuna aga loomine ilma fantaasiata on võimata, siis on ka arusaadav, mispärast muusika ajaloos pole mitte ühte tähtsamat naisheliloojat leida. Pr. Vinogradova helitöö puhul võiks Lessingi sõnu tarvitada; millega ta ühe raamatu sisu iseloomustas: 'siin on palju uut ja head, kahju ainult, et see, mis uus on, pole mitte hea ja see, mis hea - pole mitte uus.” Vaba Maa 9.12.1925; siteerannut myös Lippus 1997, 116.

17 "[...] eine Künstlerin [...], die mit Verve ihre eigenen Wege geht und zu gar keinen Konzessionen bereit erscheint." Rigasche Rundschau 1.5.1936. 
morista" (omapärased, teravameelse huumoriga nähtud soololaulud, Postimees 6.11.1936 ja 22.5.1939). Erityisesti kuitenkin suitsutettiin kymmentä lapsille suunnattua pianokappaletta opus 25. Uudisleht-lehden nimettömäksi jäänyt kriitikko nimitti opukseen sisältynyttä "Pieni sairastunut koiranpentu" -kappaletta (Kutsik jäi haigeks / Väike haige koerakene, osa VII) jopa "mestariteokseksi itsessään" (omaette meisterteos, Uudisleht 20.10.1936).

Ammatillisten profiilien eroista huolimatta Miina Härman ja Vera Vinogradova-Bieckin teosten ja konserttien vastaanotossa on nähtävissä kaksi yhtenevää, sukupuolittunutta peruslinjaa. Ensinnäkin molempiin liitettiin säveltäjinä ja esiintyvinä taiteilijoina tiettyjä naiseuteen yhdistettyjä määreitä: Härman kohdalla sävelkielen herkkyyttä, Vinogradova-Bieckin yhteydessä impulsiivisuutta ja sävellysteknistä harjaantumattomuutta. Miina Härmalle rakentuva kansallissankarin sädekehä sotilaallis-patrioottisine mielleyhtymineen korosti hänen "poikkeuksellisuuttaan" säveltävänä naisena entisestään ja - paradoksaalista kyllä - vahvisti tällä tavalla binäärisiä sukupuolirooleja musiikki- ja sanomalehtijulkisuudessa. Toiseksi sekä Vinogradova-Bieckin että Härman laajamuotoisemmat teokset jäivät jossakin määrin varjoon sanomalehtikritiikeissä ja biografia-artikkeleissa: karakterikappaleista, lauluista ja pedagogisista teoksista naisille oli lähtökohtaisesti helpompi antaa välitöntä tunnustusta kuin sävellysteknisesti vaativampina pidettyjen kamarimusiikki- tai orkesteriteosten yhteydessä.

\section{Virolainen, venäläinen, eurooppalainen? Luokka ja kulttuuritausta sukupuolittuneessa sanomalehtijulkisuudessa}

Sukupuolittuneeseen sanomalehtikirjoitteluun kietoutuivatkin oleellisesti Miina Härman ja Vera Vinogradova-Bieckin kulttuuri-, kieli- sekä luokka-asemat - eivät ainoastaan vironkielisyyden tai virolaisen kansallisuusaatteen osalta. Miina Härman kohdalla sanomalehtijulkisuuteen vaikuttivat erityisesti virolainen kansallisuusaate sekä talonpoikaisiksi mielletyt sukujuuret. Vinogradova-Bieckistä puolestaan tuli sotienvälisessä Tallinnassa venäjänkielisen emigranttiyhdistys- ja kulttuuritoiminnan aktiivi, mikä heijastui vahvasti häntä koskevaan uutisointiin. Molempien uraan ja kulttuurityöhön vaikutti oleellisesti myös sotienvälisen ajan poliittinen turbulenssi sekä Virossa että muualla Euroopassa.

Miina Härman ainutlaatuisuutta säveltävänä naisena painotettiin sanomalehdissä nimenomaisesti nationalistisessa hengessä. Artikkeleissa 
toistuu käsitys Härmasta Viron ainoana ja Pohjoismaiden tai jopa maailman merkittävimpänä naissäveltäjänä ja tässä suhteessa kansallisena ylpeydenaiheena (ks. esim. Sakala 14.2.1933; Lä̈̈ne Elu 6.7.1934; Uudisleht 4.2.1936). Totta onkin, että Härman osakseen saama julkinen tunnustus oli aikakauden säveltävälle naiselle poikkeuksellista jopa yleiseurooppalaisessa mittakaavassa. Suitsutus viestii eritoten vastaitsenäistyneessä Virossa levinneestä aatesuuntauksista, joilla pyrittiin yhtäältä tiivistämään poliittis-kulttuurisia yhteyksiä Pohjoismaihin ja toisaalta tekemään vastaitsenäistynyttä valtiota tunnetuksi muualla Euroopassa (Zetterberg 2007, 539-544). Muuan Uudisleht-julkaisun kolumnisti suorastaan nuhteli sekä virolaista naisasialiikettä että valtiovaltaa siitä, ettei Härman persoonaa ja tuotantoa markkinoitu tarpeeksi ulkomaisille yleisöille niiden imagopotentiaalista huolimatta (ks. esim. Uudisleht 4.2.1936).

Tyypillisesti Härmaa kutsuttiin lehtiartikkeleissa nimellä lauluema eli kirjaimellisesti "lauluäiti" (ks. esim. Oma Maa 9.2.1939). Käsite viittaa alkujaan arvostettuun kansanlaulajaan ja sopi sikäli Härman säveltäjäja muusikkoprofiiliin saumattomasti (Eesti keele seletav sõnaraamat). Sitä käytettiin lehdissä myös sopraano Aino Tammista (ks. esim. Uus Eesti 1.3.1939), kun taas Viron kansalliseepoksena pidetyn Kalevipoeg-runoelman kirjoittaja Friedrich Reinhold Kreutzwald - jonka muotokuva riippui Härman kotona pianon yläpuolella - tunnettiin vastaavasti lempinimellä lauluisa (ks. esim. Postimees 19.3.1930). Vaikka Härmalla ei tiettävästi ollut biologisia lapsia, (kansallis)romanttisia äiti- ja hoivamielikuvia viljeltiin laajemminkin hänestä kertovissa elämäkerrallisissa artikkeleissa (esim. Uudisleht 20.2.1938; Päevaleht 2.12.1934). Lauluematermiin kiteytyi toisin sanoen monenlaisia sukupuoleen, musiikkikulttuuriin sekä kansallisuusaatteeseen liittyviä avainviestejä. Tässä suhteessa Härmaa voi verrata Suomen musiikinhistorian merkkihenkilöksi nousseeseen kanteleensoittaja Kreeta Haapasaloon, jonka julkisuuskuva rakentui fennomaanisen nationalismin ja kansalliseksi mielletyn musiikkikulttuurin liitoskohtaan (vrt. Laitinen 2000, 27-106).

Virolaiskansallinen aatemaailma ei suinkaan ollut Miina Härman tapauksessa sanomalehdistön päälleliimaamaa sanahelinää, vaan Härma otti oma-aloitteisesti ja innokkaasti osaa erilaisten porvarillis-oikeistolaisten yhdistysten kuten suojeluskuntien ja etenkin Lotta Svärd -liikkeeseen vertautuvan Naiskodukaitse-järjestön toimintaan (esim. Päevaleht 24.6.1927; ks. myös Leskinen 2012, 12-13). Keskustaoikeistolaisissa virolaislehdissä Härmasta leivottiin 1930-luvulla jopa omanlaisensa roolimalli modernille virolaiselle naiselle (Naisterahva Töö ja Elu ja Käsitööleht 7.7.1926; Postimees 15.11.1936). Hänen elämäntyötään tulkittiin näissä 
yhteyksissä esimerkillisen väsymättömänä uurastuksena ja uhrautumisena kansankunnan puolesta (Sakala 23.2.1939; Päevaleht 6.2.1939).

Naisasialiike oli Härman sydäntä lähellä, ja sen puolesta hän otti kantaa julkisuudessa. Myöhemmällä iällä antamissaan haastatteluissa Härma totesi iloitsevansa siitä, kuinka mittavasti naisten ammatillis-yhteiskunnallinen toimintakenttä oli hänen nuoruuteensa verrattuna laajentunut (ks. esim. Päevaleht 3.2.1939). Tähän epäilemättä vaikuttivat nuoruuden syrjintäkokemukset ja aggressiiviset kritiikkiryöpyt miespuolisten kollegoiden, etenkin Konstantin Türnpun puolelta (ks. Endre et al, 2014, 77, 91). Säveltäjä-kuoronjohtaja Johannes Kappel oli aikanaan peräti uhannut erota vuoden 1894 laulujuhlatoimikunnasta, kun sen kokouksessa oli ehdotettu, että juhlaohjelmaan valitut Härman laulut johtaisi säveltäjä itse - toisin sanoen nainen (Uus Eesti 3.2.1939).

Toisaalta Härman naisasia-ajattelua väritti hänen kansallismielinen ja perheorientoitunut arvomaailmansa. Kouluttautuminen ja tiedonjano olivat lämpimästi kannustettavia piirteitä, mutta niiden tuli Härman mielestä tähdätä aviomiehen tukemiseen ja henkiseen kumppanuuteen:

Työssäkäyvistä ja yliopistossa opiskelevista naisista Miina Härma sanoo: "Se, joka jaksaa tehdä työtä ja opiskella, tehköön sitä tinkimättä. Naisen pitää nousta miehen tasolle. Miten muuten hän voisi jakaa miehen murheet ja vaivat, olla hänen arvoisensa työtoveri, jos nainen on koulutukseltaan matalammalla asteella? Korkeakoulutuksen saaminen ei vielä tarkoita, että naisen täytyy sen vuoksi välttämättä lähteä akateemiselle uralle [kateedrisse minema]. Ahkera ihminen ei voi olla ilman henkistä tointa. Laiska nainen on se, joka ei yritä kehittää itseään ja ajattelee, että on avioitumisellaan tehnyt kaiken tarvittavan." 18

Julkisuudessa Härma ei suoranaisesti esiintynyt puoluepoliittisesti aktiivisena henkilönä. Hänellä oli silti henkilökohtaisia kytköksiä 1930-luvun Viron korkeavirkaisiin keskustaoikeistolaisiin poliitikkoihin kuten pääministeri Kaarel Eenpaluun, Härman kasvatti- ja sisarentyttären Linda Eenpalun aviomieheen (Päevaleht 5.2.1921; Uus Eesti 9.5.1936

18 "Miina Härma ütleb töötavate ja ülikoolis õppivate naiste kohta: 'Kes jaksab töötada ja õppida, see tehku seda tingimata. Naine peab tõusma mehe kõrgusele. Kuis saab ta mehega jagada selle muresid ja vaeva, olla talle vääriliseks kaastööliseks, kui ta on hariduslikult madalamal tasemel? Kõrgema hariduse saamine ei tähenda veel, et naine peab sellega tingimata kateedrisse minema. Virk inimene ei saagi olla vaimlise tegevuseta. Laisk naine on see, kes ei püüa end edasi arendada ja arvab, et on abiellumisega teinud kõik vajaliku." Uudisleht 20.2.1938. 
ja 12.12.1938). Toisaalta Härman sävellykset kelpasivat kansanlaulupainotteisuutensa vuoksi 1920-luvun alussa jopa Pietarin virolaisten bolševikkien illanviettoon (Edasi 22.9.1922). Säveltäjä itse väitti selvinneensä punaisten valloittamassa Tartossa sisällissotien aikaan vahingoittumattomana siksi, että hän oli taustaltaan ja elämäntyyliltään lähellä "tavallista kansaa" (lihtrahvas) eikä häntä sen vuoksi pidetty "porvarina" (burshui [sic], Uudisleht 23.1.1939).

Miina Härman julkisuuskuvassa sukupuoleen ja kansallisuusaatteeseen kietoutuikin erottamattomasti yhteiskuntaluokka. Härma painotti haastatteluissa mielellään "talonpoikaisia" juuriaan sekä niihin liittyvää menestystarinaa: hänen isänsä oli onnistunut nousemaan huutolaispojasta kansankynttiläksi, ja perheellä oli ollut Härman lapsuudessa maatalo (Vahter 1971, 9). Tästä kansanomaisuudesta sekä luokkaretkimielikuvasta reportterit ammensivat mielellään, ja Härmaa nimitettiin artikkeleissa usein tuttavallisesti "meidän Miinaksi" (meie Miina, ks. esim. Kaja 10.2.1933).

Talonpoikaisuuteen liittyivät Miina Härman omaelämäkerrallisessa narratiivissa myös hengellisyys sekä luontoromantiikka. Sanomalehdet toistelivat Härman vuonna 1895 julkaistuja lapsuudenmuistelmia, joissa säveltäjä kertoi muun muassa improvisoineensa ensimmäiset laulumelodiansa pikkutyttönä paimenessa (ks. esim. Päevaleht 9.2.1924). Myös Härman tuotannon yhteydessä käytettiin toistuvasti maatalouteen viittaavia idiomeja ja kielikuvia: sitä pidettiin muun muassa Viron "musiikkipellon" eli musiikkielämän (muusikapõld, esim. Päevaleht 10.12.1932) "peruskalliona" eli raudvarana (esim. Päevaleht 11.2.1924). ${ }^{19}$

Agraarisen taustan ja nationalistisen uhrimielen korostuneisuus Härman julkisuuskuvassa tiivistävät sen yhteyksiä valtiovaltaan ja poliittiseen ilmapiiriin etenkin 1930-luvun lopun Virossa. Aikakautta leimasivat vahvasti pääministeri Eenpalun ja riigivanem Konstantin Pätsin autoritäärisen hallinnon lujittuminen sekä ennen pitkää demokratian ja sananvapauden kaventuminen (Zetterberg 2007, 562). Pätsin-Eenpalun talonpoikaispuolueen poliittinen aatemaailma rakentui pitkälti idealisoidun maalaiselämän ja kielellis-kulttuurisesti yhtenäisen kansakunnan ihanteille, joiden tueksi kenraali Johan Laidonerin ja oikeustieteilijä Jüri Uluotsin kaltaiset hahmot esittivät julkisuudessa kansallisromantti-

${ }^{19}$ Konkreettisessa vironkielisessä merkityksessään raudvara viittaa talonpojan korvaamattomaan ydinomaisuuteen kuten siemenviljaan, joskin sillä on myös kuvainnollinen, jonkin asian perustaan tai ytimeen liittyvä käyttötapa (Eesti keele seletav sõnaraamat). Käsitettä on tästä syystä vaikea suomentaa täsmällisesti, minkä vuoksi olen päätynyt vapaampaan kielikuvakäännökseen. 
sia historiantulkintoja (Zetterberg 2007, 560-561). Tällaisen ideologian kannalta Miina Härman persoona, kansansuosio ja tuotanto olivat kullanarvoisia propagandavaltteja. Lauluema Härma näyttäytyi talonpoikaispuolueen näkökulmasta Viron kansan musikaalisuuden ja taistelutahdon ruumiillistumana (ks. esim. Päevaleht 6.2.1939).

Erityisesti 1930-luvun lopulla Miina Härma olikin valtiollisissa tilaisuuksissa usein nähty kunniavieras, ja hän saattoi myös johtaa niissä omia teoksiaan (ks. esim. Järva Teataja 27.8.1937). Härman sävellyksiä esitettiin muun muassa Viron tasavallan vuosipäivän (vabariigi aastapäev) juhlallisuuksissa 24. helmikuuta sekä kulttuuridiplomaattisissa yhteyksissä (Postimees 24.2.1939; Teataja 8.6.1938). Härma oli tärkeä hahmo myös Viron Suomi-suhteiden kannalta (Endre et al. 2014, 107-109; Vaba Maa 17.10.1931). Kun veljentytär, pääministerin puoliso Linda Eenpalu matkusti Tallinnan naisklubin jäsenten kanssa tutustumaan Marttaliiton toimintaan toukokuussa 1939, Miina Härma oli itseoikeutetusti mukana kunniavieraan ominaisuudessa (Uus Eesti 19.5.1939; Päevaleht 19.5.1939).

Miina Härmaa ei kuitenkaan tule nähdä valtiovallan ja median passiivisena käsikassarana. Hänellä itsellään oli aktiivinen osuus oman julkisuuskuvansa luomisessa ja ylläpitämisessä, ja joskus hän osallistui myös päivänpoliittiseen keskusteluun. Kun esimerkiksi äärioikeistolaisen VAPS-järjestön sihteeri Helene Johani vuonna 1933 julkaisi virolaista naisasialiikettä vastaan hyökkäävän artikkelin, Miina Härma kuului niiden kulttuurivaikuttajien joukkoon, jotka allekirjoittivat puheenvuorolle julkisen vastineen (ks. esim. Päevaleht 12.10.1933). Vastineessa painotettiin nationalistisia arvoja ja Viron vapaussodan perintöä, mutta myös demokraattisen päätöksenteon tärkeyttä sekä naisasialiikkeen ansioita.

Vera Vinogradova-Bieck ei saavuttanut saman mittakaavan kansallista julkisuutta kuin kollegansa Härma. Siitä huolimatta, että kulttuuri- ja kielivähemmistöillä oli sotienvälisessä Virossa muodollisesti turvattu ja autonominen asema parlamenttiedustajineen sekä omine tiedotuskanavineen (Zetterberg 2007, 583-584), Vinogradova-Bieckin musiikillinen ja yhteiskunnallinen aktiivisuus noteerattiin pääasiallisesti Tallinnan venäjänkielisen yhteisön sisällä.

Jo sanomalehtikritiikeissä Vera Vinogradova-Bieckin sävellystyötä pidettiin leimallisesti venäläisenä: Viroon tai Tallinnaan sitä ei yhdistetty oikeastaan millään tavalla. Esimerkiksi Vinogradova-Bieckin pianotriosta venäjänkielisen Vesti dnjan kriitikko nosti erikseen esille motiivit ja äänenkuljetuksen, joissa hän kuuli vaikutteita kasakkalauluista sekä venäläisestä kansanmusiikista (Vesti dnja 20.10.1936 ja 22.3.1939). Myös 
Maria Judinan mielestä Vinogradova-Bieckin musiikillisessa kielessä heijastuivat jo nuoruusvuosina säveltäjän "todellinen venäläinen hellyys ja lempeys" (jejo istinno russkaja laskovost' i nežnost', Judina 1999, 113), kun taas Artur Lemba vertasi 1920-luvun kritiikeissään Vinogradova-Bieckiä Skrjabiniin ja Prokofjeviin (Vaba Maa 22.4.1923). Säilyneiden, painettujen teosten kuten Pariisissa 1930-luvulla julkaistujen pianokappaleiden rytmin käsittelyssä ja sointiväreissä voi tosiaan kuulla venäläisen modernismin ja myöhäisromantiikan vaikutteita (ks. erityisesti VinogradovaBieck 1930a).

Miina Härman tapaan myös Vera Vinogradova-Bieck oli aloitteellisesti ja tarmokkaasti mukana yhdistystoiminnassa. Hän osallistui 1920ja 1930-luvuilla Tallinnan venäjänkielisten järjestöjen toimintaan niin hyväntekeväisyyskonserteissa kuin luentoilloissakin (Poslednija izvestija 3.12.1922; Vesti dnja 18.3.1934). Erityisen innokkaasti Vinogradova-Bieck oli mukana Venäläisen kirjallisuuspiirin (Russkij literaturnyj kružok) illanvietoissa, joissa hän esitti edistyneempien oppilaidensa kanssa nelikätisesti pianokonserttoja ja joskus jopa soitti itse omia sävellyksiään (Vesti dnja 24.11.1926 ja 9.9.1927).

Valtaosa Vera Vinogradova-Bieckin pianostudion opiskelijoista oli venäjänkielisiä, ja hän vaikutti siis myös tässä suhteessa Tallinnan venäjänkielisen yhteisön kulttuurielämään. Esimerkiksi Vesti dnja -lehden reportteri ilmoitti ylpeänä Vinogradova-Bieckin kolmen poikkeuslahjakkaan oppilaan konsertin jälkeen kesäkuussa 1935, että kaikilla kolmella nuorella pianistilla oli venäläisiä sukujuuria (Vesti dnja 5.6.1935). Ylipäätään Vinogradova-Bieckin pianostudion julkiset oppilasnäytteet arvioitiin tarkasti venäjänkielisissä lehdissä, ja niissä esitettiin hänen omia teoksiaan (esimerkkinä ks. Vesti dnja 18.9.1928). Ainakin kertaalleen säveltäjä myös johti itse orkesteria oppilaskonsertissaan (Vesti dnja 18.2.1934). Pianoluokan jäähyväiskonsertissa kesällä 1927 muuan vanhemmista totesi puolestaan juhlapuheessaan näin: "Aikaisemmin oli meidän lapsemme väkipakolla raahattava flyygelin ääreen, nykyään heitä ei saa raahattua sen luota pois." ${ }^{20}$ Kun lähdön aika koitti, Tallinnan juna-asemalle kokoontui kukkien kera runsaasti väkeä Vinogradova-Bieckiä saattamaan ja hyvästelemään (Vesti dnja 9.9.1927). Jotkut lahjakkaimmista oppilaista, kuten Tamara Gorbatšova, seurasivat opettajaansa Berliiniin ja täydensivät opintojaan Hermann Bieckin johdolla Scharwenka-konservatoriossa (ks. esim. Tallinskij russkij golos 9.9.1933).

20 ”Раньше [...] приходилось нашихъ дьтей насильно гнать къ роялю, теперь их нельзя отогнать оть него.” Vesti dnja 3.6.1927. 
Vaikka Vera Vinogradova-Bieckin kulttuuritoiminta keskittyi Tallinnan venäjänkieliseen yhteisöön, hän sai pienen jalansijan myös kansallisessa julkisuudessa. Bieckien asuessa Berliinissä ja Lontoossa heitä nimittäin kutsuttiin soittamaan Viron-lähetystöjen tilaisuuksiin muun muassa tasavallan vuosipäivän juhlallisuuksien yhteydessä (Postimees 3.3.1928; Päevaleht 13.11.1934). Tähän myötävaikuttivat erityisesti Hermann Bieckin tallinnalainen syntyperä ja Tallinnassa Alice Segalin maineikkaasta pianokoulusta alkanut musiikkiura. ${ }^{21}$ Kumpikaan puolisoista ei silti loppujen lopuksi istunut itsenäistyneen Viron rakenteilla olevaan musiikkikaanoniin. Tähän vaikuttivat epäilemättä Vera VinogradovaBieckin venäläinen ja Hermann Bieckin juutalainen tausta sekä molempien taiteelliset intressit, jotka eivät ankkuroituneet virolaiskansallisiksi katsottuihin elementteihin vaan pikemminkin yleiseurooppalaiseen modernismiin. Lisäksi pariskunta oli alun perin asettunut Pietariin, eikä heille suhdeverkostostaan huolimatta ehtinyt rakentua pysyvää institutionaalista asemaa virolaisessa musiikkielämässä toisin kuin jo ensimmäisen maailmansodan pyörteissä Tarttoon asettuneelle Miina Härmalle.

Sekä Vera Vinogradova-Bieckin että Miina Härman poliittisessa ja yhteiskunnallisessa toiminnassa riittää vielä runsaasti selvitettävää. Olisi eettisesti kyseenalaista tehdä pitkälle meneviä johtopäätöksiä heidän poliittisista näkemyksistään pääasiallisesti sanomalehtiaineiston perusteella. Heidän saavuttamaansa laajaa julkisuutta voi kuitenkin lehtijuttujen pohjalta tulkita Princen ja Bullin huomioihin nojautuen kenttänä, jolla oli mahdollista sekä haastaa että vahvistaa sotienvälisen ajan sukupuoli-, kansallisuus- ja luokkanormeja. Miina Härman kohdalla vaaka kallistui useimmiten vahvistamisen puolelle. Toisaalta Härman saavuttama julkinen arvostus ja esikuvamainen asema loivat toivoa ja uskallusta nuorille naisoletetuille muusikoille, joiden haaveissa siinsi ura miesvaltaisella kuoronjohdon alalla (Vahter 1971, 148). Vera Vinogradova-Bieckin julkisuuskuvaa sen sijaan määrittävät pitkälti vähemmistöasema sekä ekspressionistinen, kokeileva sävellystyyli. Bullin ja Princen ajatuksia soveltaen hänen julkisuuskuvansa näyttäytyy tästä syystä eri tavalla vastahankaisena kuin Miina Härman saavuttama julkinen suosio. Nuoresta venäjänkielisestä modernistista olisi ollut mahdotonta leipoa Härman kaltaista kansallisen tason esikuvaa aikakauden poliittisessa ilmapiirissä.

${ }^{21}$ Ks. esim. Päevaleht 7.2.1924; Segalista ks. myös Lippus 1997, 19-22. 


\section{Johtopäätökset}

Tarkasteltaessa Miina Härman ja Vera Vinogradova-Bieckin musiikkitoimintaa rinta rinnan tulee harvinaisen selväksi, miten monimutkaisen, keskenään risteävän vyyhdin sukupuoli, kieli, kulttuuritausta ja sosioekonomiset tekijät sotienvälisen ajan säveltävien naisten urapoluilla muodostivat. Härman kaltaista säveltäjää voitiin suitsuttaa julkisuudessa nationalistisessa hengessä, mutta kaikki musiikkimaailman ovet eivät hänellekään avautuneet. Naisena Härma jäi väistämättä poikkeukseksi, ja hänen saavutuksensa määriteltiin sukupuolittuneen säveltäjästandardin mittatikkua vasten.

Miina Härman poikkeuksellisuuden korostamisella toimittajat epäsuorasti vahvensivat binäärisiä ja heteronormatiivisia sukupuolirooleja nuoressa kansallisvaltiossa. Vinogradova-Bieck puolestaan muodosti säveltaiteen patriarkaaliselle, kansallis-konservatiiviselle kentälle toisentyyppisen uhan. Säveltäjänaisten saavuttama julkisuus ei aina automaattisesti särkenyt lasikattoja, vaan keskustelu saattoi saada kirjoittajasta ja julkaisualustasta riippuen monenlaisia, sukupuolirooleja venyttäviä tai niitä entuudestaan kaventavia sävyjä.

Musiikkikritiikkiä ja -lehtikirjoittelua säätelivät sotienvälisessä Virossa ylipäätään toimittajien, säveltäjien ja poliitikkojen miesvaltaiset ammattikunnat. Miina Härmalla oli kuitenkin merkittävä yhteiskunnallinen ja kulttuuripoliittinen auktoriteettiasema, jota hän itse rakensi ja hyödynsi ja jonka puitteissa hän pääsi haastatteluissa tuomaan kuuluville omaa ääntään. Vera Vinogradova-Bieckin kaltaiselle kielivähemmistön edustajalle tällainen ei ollut mahdollista. Sosioekonomisesti katsottuna Härman valttina oli varsinkin 1930-luvun keskustaoikeistolaisessa julkisessa keskustelussa vaalittu "talonpoikainen" tausta, kun taas Vinogradova-Bieckin ammatillinen suhdeverkosto rakentui uudessa kotimaassa pitkälti konservatoriotuttavuuksille. Härman ja Vinogradova-Bieckin julkisuuskuvista hahmottuvatkin eräänlaiset rinnakkaiset, yhtäältä nationalistisen liikehdinnän ja valtiovallan sekä toisaalta Tallinnan venäläisen emigranttipiirin ylirajaiset todellisuudet.

Osaltaan kysymys oli myös säveltäjäprofiilien, sukupolvien sekä ammatillisten tavoitteiden eroista. Miina Härma tähtäsi uransa alusta saakka vironkielisen kulttuurin kansallisromanttiseen edistämiseen ja erikoistui säveltäjänä vokaalimusiikkiin. Vinogradova-Bieck sen sijaan edusti nuoremman sukupolven musiikillista ekspressionismia keskittyen tuotannossaan kamarimusiikki-, piano- ja orkesteriteoksiin. Myös Här- 
ma teki nuoruudessaan ja myöhemminkin konserttimatkoja ulkomaille, mutta Vinogradova-Bieckin tähtäimessä oli sotienvälisenä aikana selkeämmin kansainvälinen solisti- ja säveltäjäura.

Musiikkikritiikissä kummankin säveltäjän teosten vastaanottoon vaikuttivat alan miesvoittoisuus ja sukupuolittuneet asenteet. Molempien kohdalla arvostelijat painottivat laulujen, karakterikappaleiden ja lastenmusiikin arvoa mutta suhtautuivat kriittisemmin orkesteri- ja näyttämöteoksiin. Myös moitteiden kohteet olivat osittain yhtenevät huomattavista tyylillisistä eroista huolimatta: suurten linjojen ja riittävän mielenkiintoisten omaperäisten ajatusten puute sekä sävellystekniikan harjaantumattomuus. Vinogradova-Bieckin kohdalla kritiikki tosin kohdistui erityisesti modernistiseen sävelkieleen, ja samasta moitittiin myös hänen säveltäjäpuolisoaan. Vironkieliset arvioitsijat olivat lisäksi VinogradovaBieckin teoksia arvioidessaan avoimemman seksistisiä kuin kansallisaarteena pidetyn ja iäkkäämpää sukupolvea edustavan Härman suhteen.

Sekä Vera Vinogradova-Bieckin että Miina Härman elämä ja tuotanto kaipaisivat tulevaisuudessa kriittistä biografista sekä musiikkitieteellistä analyysia perustutkimustasolla. Säveltäjien oma ääni on päästettävä kuuluville esimerkiksi kirjeaineiston avulla. Heidän sanomalehtijulkisuutensa tarkastelu osoittaa silti, miten tärkeää sanomalehtitekstien sukupuolittuneisuuden hienovarainen, intersektionaaliset tekijät huomioiva lähiluku on 1800- ja 1900-luvun naisoletettujen säveltäjien kohdalla. Julkinen keskustelu ei miesvaltaisuudestaan huolimatta mahdollistanut ainoastaan olemassa olevien sukupuoliroolien puolustamista, vaan myös niiden raamien laajentamista - joko suoralla tai epäsuoralla tavalla.

\section{Lähteet}

\section{Arkistolähteet}

Saatavilla SAAGA- ja Estlatrus-arkistoportaalien kautta, http://www.ra.ee/dgs/explorer.php, tark. 15.2.2021 \& http://earchive-estlatrus.eu, tark. 13.5.2021.

Eesti Evangeelne Luterlik Kirik (EELK)

Tallinna Niguliste Kogudus, II personaalraamat, TLA.31.2.25, s. 22/23

Tallinna Aadressbüroo (TAB), Aadresslehed

TLA.1376.1.22, Biek, Herman \& Biek, Weera (1927)

Tallinna ja Nõmme isikutunnistuste kollektsioon (TNI)

TLA.186.1.457, Isikuntunnistutse kontsud, Politsei VI jaoskond, 10868 Biek, Weera, Paul 
TsGIA SPB [ЦГИА СПБ, Pietarin historiallinen valtionarkisto]

Fond 361 (Pietarin konservatorion arkisto), opis' 2, litšnye dela utšenits, German, Minna [Ф. 361 опись 2 (личные дела учениц), Германъ, Минна]

\section{Sanomalehdet}

Saatavilla Viron kansalliskirjaston DIGAR- ja Latvian kansalliskirjaston Periodika-arkistoportaalien kautta, https://dea.digar.ee \& http://periodika.lv, tark. 14.2. ja 15.2.2021.

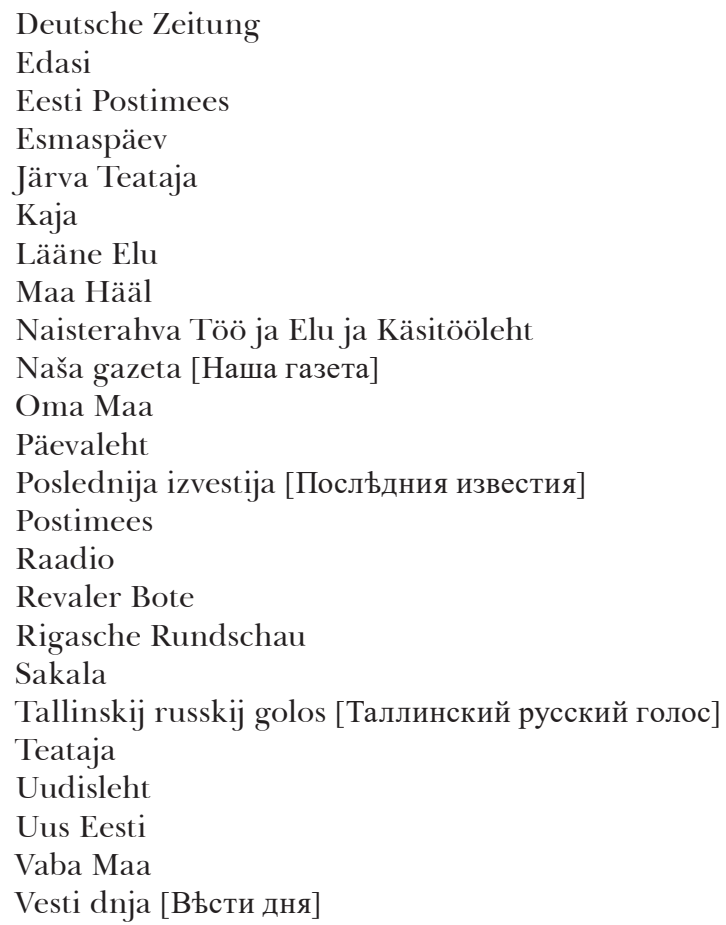

\section{Muut painetut lähteet}

Brook, Peter. 2017. Threads of Time: A Memoir. London: Bloomsbury.

Judina, Maria [Юдина, Мария]. 1999. Lutši božestvennoj ljubvi: literaturnoje nasledie. [Лучи Божественной Любви: Литературное наследие]. Moskva \& Sankt Peterburg: Universitetskaja kniga [Москва \& СПБ: Университетская книга].

Judina, Maria [Юдина, Мария]. 2006. Vysokij stoikij duh: Perepiska 1918-1945 gg. [Высокий стойкий дух: Переписка 1918-1945 г2.]. Moskva: ROSSPEN [Москва: РОССПЭН].

Vinogradova-Bieck, Vera. 1930a. Quatre Épisodes sur un thème pour piano, op. 20. Paris: Édition russe de musique. 
Vinogradova-Bieck, Vera. 1930b. Tempo marciale pour piano, op. 20. Paris: Édition russe de musique.

Vinogradova-Bieck, Vera. 1933. Deux Danses pour piano, op. 21. Paris: Édition russe de musique.

\section{Tutkimuskirjallisuus}

Belobrovtseva, Irina ja Aurika Meimre. 2015. "Sõdadevaheline vene emigratsioon suures ilmas ja väikeses Eestis". Methis, Studia Humaniora Estonica 15: 28-46. https:// doi.org/10.7592/methis.v12i15.12114.

Bull, Anna. 2019. Class, Control, and Classical Music. Oxford: Oxford University Press. https://doi.org/10.1093/oso/9780190844356.001.0001

Citron, Marcia J. 2000 [1993]. Gender and the Musical Canon, Urbana \& Chicago: University of Illinois Press.

Dolan, Jill. 2012 [1988]. The Feminist Spectator as Critic. Ann Arbor: University of Michigan Press.

Ege, Samantha. 2018. "Florence Price and the politics of her existence". The Kapralova Society journal 16 (1): 1-10.

Ege, Samantha. 2020. "Composing a Symphonist: Florence Price and the Hand of Black Women's Fellowship". Women and Music: A Journal of Gender and Culture 24: 7-27. https://doi.org/10.1353/wam.2020.0010

Frigren, Pirita. 2017. "Tirkistelyä vai ymmärryksen lisäämistä? Historioitsija arkaluontoisista asioista kirjoittamassa". Teoksessa Historiantutkimuksen etiikka, toim. Satu Lidman et al., 51-70. Helsinki: Gaudeamus.

Endre, Sirje et al., toim. 2014. Miina Härma 150: enne ja nü̈d. Tartu: Tartu linnavalitsus.

Enefalk, Hanna. 2008. En patriotisk drömvärld. Musik, nationalism och genus under det långa 1800-talet. Uppsala: Uppsala universitet.

Grotjahn, Rebecca. 2012. "Playing at Refinement: A Musicological Approach to Music, Gender and Class Around 1900". German History 30 (3): 395-411. https://doi. org/10.1093/gerhis/ghs064

Hoffmann, Freia. 1998. Instrument und Körper: Die musizierende Frau in der bürgerlichen Kultur. Frankfurt am Main: Insel Verlag.

Isakov, Sergei \& Tatjana Šor, toim. 2016-2017. Хроника русской культурной и общественной жизни в Эстонии (1918-1940): из истории русского зарубежья [Hronika russkoj kul'turnoj i obštšestvennoj žizni v Estonii (1918 -1940): iz istorii rysskogo zarubeža]. Tallinn: Aleksandra.

Kaufmann, Dorothea. 1997. “...routinierte Trommlerin gesucht". Musikerin in einer Damenkapelle zum Bild eines vergessenen Frauenberufes aus der Kaiserzeit. Schriften zur Popularmusikforschung 3. Karben: CODA Verlag.

Laitinen, Heikki. 2000. Matkoja musiikkiin 1800-luvun Suomessa. Väitöskirja, Tampereen yliopisto.

Leskinen, Anni. 2012. ”Eiväthän naiset tappamaan lähde! Keskustelua naisten aseistamisesta Eesti Naiskodukaitse -järjestössä vuosina 1925-1940". Pro gradu -tutkielma, Itä-Suomen yliopisto.

Lippus, Urve. 1995. "The Tradition of Writing on Estonian Music History". Teoksessa Music History Writing and National Culture, toim. Urve Lippus, 37-43. Tallinn: Eesti keele instituut. 
Lippus, Urve, toim. 2000. Valgeid laike eesti muusikaloost. Tallinn: Eesti Muusikaakadeemia.

Lippus, Urve, toim. 2002. Rahvuslikkuse idee ja eesti muusika 20. sajandi algupoolel. Tallinn: Eesti Muusikaakadeemia.

Lippus, Urve ja Katri Steinbach, toim. 2005. Muusikaelu Eestis 20. sajandi algupoolel. Tallinn: Ema muusikateaduse osakond.

Lippus, Urve ja Meeli Sedrik, toim. 2008. 19. sajandi muusikaelu Eestis. Tallinn: Eesti Muusika- ja Teatriakadeemia.

Lippus, Virve. 1997. Eesti pianistliku kultuuri kujumine, toim. Urve Lippus. Tallinn: Eesti Muusikaakadeemia.

Prince, April L. 2017. ”(Re)Considering the Priestess: Clara Schumann, Historiography, and the Visual". Women and Music: A Journal of Gender and Culture 21: 107-140. https://doi.org/10.1353/wam.2017.0007

Puderbaugh, David John. 2006. My Fatherland is My Love: National Identity and Creativity and the Pivotal 1947 Soviet Estonian National Song Festival. Väitöskirja, University of Iowa.

Raeff, Marc. 1990. Russia Abroad: A Cultural History of the Russian Emigration, 1919 1939. Oxford: Oxford University Press.

Rantanen, Saijaleena. 2013. "Laulu- ja soittojuhlat suomalaisen kansakunnan rakentajina 1800-luvun lopulla". Musiikki 43 (3-4): 61-84.

Sarv, Vaike. 2002. "Rahvaviiside kogumisest Eestis 19. saj. lópus ja 20. sajandi alguses". Teoksessa Rahvuslikkuse idee ja eesti muusika 20. sajandi algupoolel, 270-315. Tallinn: Eesti Muusikaakadeemia.

Scharff, Christina. 2017. Gender, Subjectivity, and Cultural Work: The Classical Music Profession. London: Routledge. https://doi.org/10.4324/9781315673080

Torvinen, Juha. 2020. "Ääriajattelu uhkaa taidemusiikkikulttuuria". Suoni ry:n blogi. Tark. 26.5.2021. https://www.suoni.fi/etusivu/2020/10/16/aariajattelun-uhka.

Vahter, Artur. 1971. Miina Härma. Tallinn: Eesti Raamat.

Yoshihara, Mari. 2008. Musicians from a Different Shore: Asians and Asian Americans in Classical Music. Philadelphia: Temple University Press.

Zetterberg, Seppo. 2007. Viron historia. Helsinki: SKS.

\section{Internet-lähteet}

Eesti keele seletav sõnaraamat. Tark. 14.2.2021. https://www.eki.ee/dict/ekss,

Entsiklopeditšeskij slovar' Sankt-Peterburgskaja konservatorija [Энциклопедический словарь Санкт-Петербургская консерватория]. Tark. 14.2.2021. http://es.conservatory. ru.

- Aleinikov, M. I. \& Seliverstova, N. В. [Алейников М. И. \& Селиверстова Н.Б.] ” Витол (Витоль, Vītols, Витолс), Язеп (Jāzeps, Язепс, Язеп Янович, Иосиф Иванович)", 2014

- Mihejeva, M. V. ”Vinogradova, Vera Pavlovna”. [Михеева, М. В. ”Виноградова, Вера Павловна"], 2019

- Vypuskniki [Выпускники] 1865-1917

Pietarin konservatorion arkiston aineistoluettelo (ЦГИА СПБ). Tark. 14.2.2021. https://spbarchives.ru/infres/-/archive/cgia/361/2.

Rybak, Mark. O Bikah [О Биках]. Eesti Juudi Muuseum, Tark. 14.2.2021. https:// muuseum.jewish.ee/stories/Biek_ru.htm. 


\section{Liite: Luettelo Vera Vinogradova-Bieckin sävellyksistä 1920- ja 1930-luvuilla ${ }^{22}$}

\begin{tabular}{|l|l|l|l|}
\hline Nimi & Opus & $\begin{array}{l}\text { Instru- } \\
\text { mentaatio }\end{array}$ & $\begin{array}{l}\text { Ensimmäinen tiedossa } \\
\text { oleva esitys / julkaisu }\end{array}$ \\
\hline
\end{tabular}

\begin{tabular}{|l|l|l|l|}
\hline Šestvije [Шествие] & Pf & $\begin{array}{l}\text { Es. 11.2.1921 Pietari } \\
\text { (VVB) }\end{array}$ \\
\hline 6 preludia & $\begin{array}{l}\text { op. } 2 \\
{[?]}\end{array}$ & Pf & $\begin{array}{l}\text { Es. 11.2.1921 Pietari } \\
\text { (VVB) }\end{array}$ \\
\hline Preludi ja fuuga & Pf & $\begin{array}{l}\text { Es. 11.2.1921 Pietari } \\
\text { (VVB) }\end{array}$ \\
\hline Sonaattifantasia & op. 4 & Pf & $\begin{array}{l}\text { Es. 15.3.1922 Tallinna } \\
\text { (VVB) }\end{array}$ \\
\hline Sarja & op. 7 & Vl, Pf & $\begin{array}{l}\text { Es. 15.3.1922 Tallinna } \\
\text { (VVB ja A. Papmehl) }\end{array}$ \\
\hline $\begin{array}{l}\text { Muurahainen ja hei- } \\
\text { näsirkka, menuetti }\end{array}$ & Pf & $\begin{array}{l}\text { Es. 15.3.1922 Tallinna } \\
\text { (VVB) }\end{array}$ \\
\hline $\begin{array}{l}\text { On mnje nje brat [Oн } \\
\text { мне нe бpat] }\end{array}$ & Voc, Pf & $\begin{array}{l}\text { Es. 15.3.1922 Tallinna } \\
\text { (VVB, Zinaida Jurjevs- } \\
\text { kaja) }\end{array}$ \\
\hline $\begin{array}{l}\text { Pianokonsertto no 1 } \\
\text { E-duuri }\end{array}$ & op. 18 & Pf & $\begin{array}{l}\text { Es. 20.4.1924 Tallinna } \\
\text { (VVB, Estonia-sinfonia- } \\
\text { orkesteri, joht. Hermann } \\
\text { Bieck) }\end{array}$ \\
\hline $\begin{array}{l}\text { Quatre épisodes sur un } \\
\text { thème }\end{array}$ & Pf, O & $\begin{array}{l}\text { Es. 4.12.1925 Tallinna } \\
\text { (Nikolai Orloff, Estonia- } \\
\text { sinfoniaorkesteri, joht. } \\
\text { Hermann Bieck) }\end{array}$ \\
\hline $\begin{array}{l}\text { Julk. Édition russe de } \\
\text { musique, Paris / Berlin } \\
1930\end{array}$
\end{tabular}

${ }^{22}$ Vera Vinogradova-Bieckin teoksista ei ole julkaistu aiemmin luetteloa, kun taas Miina Härman sävellykset on varsin kattavasti katalogisoitu esimerkiksi vuonna 2014 julkaistussa juhlakirjassa (Endre et al. 2014). Tästä syystä olen sisällyttänyt vain tämän luettelon artikkelin liitteeksi. Luettelo on koottu artikkelissa käytetyn aineiston sekä kirjastojen (Bibliothèque nationale de France, WorldCat) bibliografiatietokantojen perusteella. Lista ei suinkaan ole täydellinen ja tarkentuu varmasti tulevan tutkimuksen myötä. Listattujen teosten lisäksi lähteistä käy ilmi, että useita toistaiseksi identifioimattomia Vinogradovan romansseja sekä karakterikappaleita pianolle soitettiin Virossa 1920- ja 1930-luvuilla. 


\begin{tabular}{|c|c|c|c|}
\hline Tempo marciale & op. 20 & Pf & $\begin{array}{l}\text { Julk. Édition russe de } \\
\text { musique, Paris } 1930\end{array}$ \\
\hline $\begin{array}{l}\text { Deux danses } \\
\text { I Moderato } \\
\text { II Allegro }\end{array}$ & op. 21 & $\mathrm{Pf}$ & $\begin{array}{l}\text { Julk. Édition russe de } \\
\text { musique, Pariisi 1933; } \\
\text { levyttänyt Viviane Goer- } \\
\text { gen } 2019\end{array}$ \\
\hline Polka & & Pf & $\begin{array}{l}\text { Es. 18.2.1934 [?] Tallin- } \\
\text { na (Leo Bieck) }\end{array}$ \\
\hline $\begin{array}{l}\text { Jousikvartetto } \\
\text { I. Allegro } \\
\text { II. Andante } \\
\text { III. Intermezzo } \\
\text { IV. Finale }\end{array}$ & op. 24 & $\begin{array}{l}2 \mathrm{Vl}, \text { Vla, } \\
\text { Vc }\end{array}$ & $\begin{array}{l}\text { Es. 7.11.1934 Tallinna } \\
\text { (Rudolf Palm, Herbert } \\
\text { Laan, Artur Saat, August } \\
\text { Karjus) }\end{array}$ \\
\hline $\begin{array}{l}10 \text { pilti lastest [tableaux } \\
\text { d'enfants] } \\
\text { I. Koolivaba } \\
\text { II. Mänguhoos } \\
\text { III. Väike ratsur } \\
\text { IV. Mustadel klahvidel } \\
\text { V. Kurb meeleolu } \\
\text { VI. Fugato } \\
\text { VII. Kutsikas jäi haigeks } \\
\text { VIII. Elu laanes } \\
\text { IX. Pettumus } \\
\text { X. Marss } \\
\end{array}$ & & & $\begin{array}{l}\text { Julk. Balan, Berliini } \\
\text { 1933; es. 7.11.1934 Tal- } \\
\text { linna (VVB) }\end{array}$ \\
\hline Funérailles & op. 8 & $\mathrm{Pf}$ & $\begin{array}{l}\text { Es. 7.11.1934 Tallinna } \\
\text { (VVB) }\end{array}$ \\
\hline Kaksi tanssia & $\begin{array}{l}\text { op. } 22 \\
\text { [21?] }\end{array}$ & Pf & $\begin{array}{l}\text { Es. 7.11.1934 Tallinna } \\
\text { (VVB) }\end{array}$ \\
\hline \begin{tabular}{|l|} 
Trio \\
\end{tabular} & op. 27 & Vl, Vc, Pf & $\begin{array}{l}\text { Es. 19.10.1936 Tallinna } \\
\text { (VVB Rudolf Palm, Au- } \\
\text { gust Karjus) }\end{array}$ \\
\hline Funèbre & & $\mathrm{O}$ & $\begin{array}{l}\text { Es. 24.3.1939 Tallinna } \\
\text { (Estonia-sinfoniaorkeste- } \\
\text { ri, joht. Raimund Kull) } \\
\end{array}$ \\
\hline Toccatina & op. 29 & Pf & $\begin{array}{l}\text { Julk. Augener, Lontoo } \\
1938\end{array}$ \\
\hline Balladi & & Pf, O & $\begin{array}{l}\text { [sanomalehtimaininta } \\
\text { 1934] }\end{array}$ \\
\hline Sarja & & $2 \mathrm{Pf}$ & $\begin{array}{l}\text { [sanomalehtimaininta } \\
\text { 1934] }\end{array}$ \\
\hline
\end{tabular}

